Florida International University FIU Digital Commons

$8-1984$

\title{
The development of a risk prevention safety and security program and its application into selected Miami hotels
}

John Cochran

Florida International University

DOI: $10.25148 /$ etd.FI14060863

Follow this and additional works at: https://digitalcommons.fiu.edu/etd

Part of the Hospitality Administration and Management Commons

\section{Recommended Citation}

Cochran, John, "The development of a risk prevention safety and security program and its application into selected Miami hotels" (1984). FIU Electronic Theses and Dissertations. 2392.

https://digitalcommons.fiu.edu/etd/2392 
The development of a risk prevention safety and security program for the major problem areas of hotel operations and an evaluation of randomly selected hotels to determine if they meet the criteria set forth by this program.

by

John Cochran

A thesis submitted in partial fulfillment of the requirements for the degree of

Master of Science

in

Hotel and Food Service Management

at

Florida International University

August 1984 
The Development of a Risk Prevention Safety and Security Program and Its Application into

Selected Miami Hotels

by

John Cochran

A thesis submitted in partial fulfillment of the requirements for the degree of

Master of Science

in

Hotel and Food Service Management

at

Florida International University

Committee in charge:

Professor: Dr. Elio Bellucci, Chairperson

Professor: Steven Moll

August 1984 
To Professors: Dr. Elio Bellucci

Steven $\mathrm{MOll}$

This thesis, having been approved in respect to form and mechanical execution is referred to you for juagment upon its substantial merit.

Dean Anthony G. Marshall

School of Hospitality Management

This thesis of John Cochran is approved.

Professor

Professor

August 1984 
TABLE OF CONTENTS

Section

Page

I. THE PROBLEM AND ITS SETTING . . . . . . . . . 1

The statement of the Problem . . . . . . . . . I 1

The statement of the Subproblems . . . . . . . 1

The Hypotheses . . . . . . . . . . . . . 1

The Delimitations . . . . . . . . . . . . . 2

The Definition of the Terms . . . . . . . . . 2

The Assumptions . . . . . . . . . . . . . . 2

The Importance of the study . . . . . . . . . 3

II. THE REVIEW OF THE RELATED LITERATURE . . • . . 7

A. The Historical Perspective . . . . . . 7

Introduction ............ . 7

The English Inn . . . . . . . . . . 8

The American Inn . . . . . . . . . . . . 11

B. Understanding Hospitality Law . . . . . . 16

C. An Overview of Hotel Safety and Security Today . . . . . . . . . . . . 19

D. The Future of Risk Management Safety and Security ............. . 27

E. Summary ............... . 32

III. THE DEVELOPMENT OF THE RISK PREVENTION SAFETY AND SECURITY MANUAL . . . . . . . . . . . 36

Introduction . . . . . . . . . . . . 36

A. The General Hotel Safety and Security
program..... . . . . . . . 39

Property Characteristics . . . . . . 40

Access Control . . . . . . . . . . . 41

Employee Awareness . . . . . . . . . 44

Housekeeping . . . . . . . . . . . . 44

Pool Review . . . . . . . . . . . . 45

Routine Safety Rules... . . . . . . 46

B. Personnel............. . . 47

Introduction . . . . . . . . . . . . . . . 47

The Development of An Effective Personnel

Program ................ 48

Job Descriptions . . . . . . . . . 48

Interviewing . . . . . . . . . . 50 
D. Iighting . . . . . . . . . . . . 73

Introduction ............. . . . . 73

Indoor Lighting . . . . . . . . . . . 75

Incandescent Lighting . . . . . . . 75

Fluorescent Lighting . . . . . . . 75

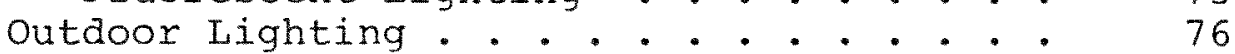

Developing an Effective Lighting

Program . . . . . . . . . . . . 77

Conclusion

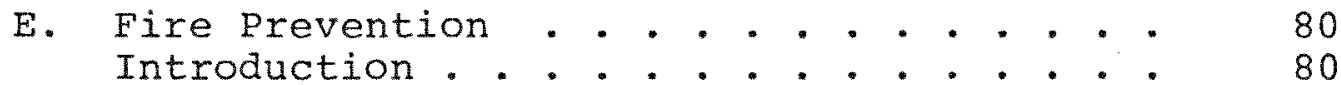

Types of Fires............... 82

Developing an Effective Fire Prevention

Program ................. 83

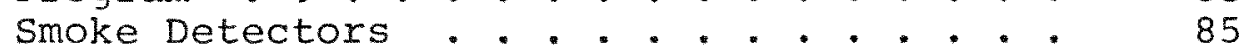

Fire and the Media.. . . . . . . . . 86

Conclusion . . . . . . . . . . . . 88

IV. GENERAL PROCEDURES . . . . . . . . . . . . 93

General Overview . . . . . . . . . . 93

The Research Methodology . . . . . . . 93

The Treatment of the Data . . . . . . 94

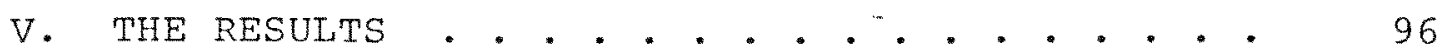

The Completed Survey Returns . . . . . . . . 96

Hypothesis I. . . . . . . . . . . . . . 96

Hypothesis II . . . . . . . . . . . . . 108 
VI. SUMMARY, CONCLUSIONS AND RECOMMENDATIONS . . . 109

Appendix A . . . . . . . . . . . . . . . . . 113

Bibliography . . . . . . . . . . . . . . . . 115 


\section{LIST OF TABLES}

Table

Page

I. The Hotel Safety and Security Section . . . . . 102

II. Personnel . . . . . . . . . . . . . . . 104

II. Key and Lock Control . . . . . ... . . 105

IV. Lighting . . . . . . . . . . . . . . 106

V. Fire Prevention . . . . . . . . . . . . 107 


\section{$\underline{\text { ABSTRACT }}$}

The development of a risk prevention safety and security program for the major problem areas of hotel operations and an evaluation of randomly selected hotels to determine if they meet the criteria set forth by this program.

\section{by}

John Cochran

The purpose of this thesis is to develop a risk prevention safety and security program for the major problem areas of hotel operations. This includes general hotel safety and security, personnel, lock and key control, lighting and fire prevention. It will then evaluate randomly selected hotels in the Miami area to determine how well they meet the criteria set forth in this program.

This thesis will use related texts, periodicals and published articles to develop a the risk prevention safety and security program. The data to determine how well selected Miami hotels responded to this program 
was developed through the use of a detailed questionaire.

The major finding was that the majority of hotels have adequate $x$ isk prevention safety and security programs set forth in writing as part of the overall hotel management function. However, the hotels surveyed failed to implement these programs into daily operations.

Survey members agreed if the hotels could consolidate the risk prevention safety and security program into a singular management function then a valuable management tool would be created. 


\section{SECTION I}

THE PROBLEM AND ITS SETTING 
SECTION I. THE PROBLEM AND ITS SETTING

The statement of the Problem

This research proposes to analyze and develop a risk prevention safety and security program for the major problem areas of hotel operations which include general hotel safety and security, personnel, lock and key control, lighting and fire prevention and then to evaluate how well selected hotels in the Miami area meet the criteria set forth in this program.

The statement of the subproblems

The first subproblem is to analyze and develop a risk prevention safety and security program for these major problem areas of hotel operations.

The second subproblem is to evaluate how well selected hotels in the Miami area meet the criteria set forth in this program.

\section{The Hypotheses}

The first hypothesis is that a need does exist for hotel management to re-address these major problem areas in hotel operations.

The second hypothesis is that this risk prevention safety and security program can be effectively implemented within these major problem areas of hotel operations and subsequently reduce these problem areas. 
The Delimitations

This research will involve hotel businesses currently in operation.

This study will not attempt to offer final solutions to the major problem areas of hotel operations.

The Definition of the Terms

Risk Management. The method by which any business or person utilizes economical methods to control the risk of losses and potential losses where insurance is the last resort rather than the first. ${ }^{1}$

Hotel. Any public lodging establishment containing sleeping room accommodations for 25 or more guests and providing services generally associated with and recognized as a hotel in the community in which it is situated or by the industry is a hotel. ${ }^{2}$

Security. The necessary precautions taken by a business or person or persons to protect assets from theft, injury and other dangers. ${ }^{3}$

Safety. The physical or emotional state of being free from injury or danger or the occurrence of injury or danger.

The Assumptions

The first assumption. The first assumption is that many hotels regardless of size or type have within the hotel operation a risk prevention program. 
The second assumption. The second assumption is that many hotels donot adequately implement risk prevention safety and security programs within their management of hotel operations. The third assumption. The third assumption is that with the tremendous increase in litigation against hotels regarding safety and security matters and their relationship to the major problem areas of hotel operations reviewed in this thesis, hotel managements ability to provide adequate risk prevention safety and security programs will become a major factor in that hotels success.

The Importance of the Study

The purpose of this study is to consolidate the major prolem areas in hotel operations into a singular management responsibility. This thesis will provide insight and strategies regarding th effective havding of each problem area. These specific problem areas reviewed are general hotel safety and security, personnel, lock and key control, lighting and fire prevention. This study is designed to ultimately protect the lives of hotel guests and employees by reducing the risk for losses using the most practical methods available.

This study is important to all hotels especially the smaller hotel properties. The smaller often independently owned properties donot traditionally have the budget, nor the manpower to provide a proper risk prevention safety and security program for guests and employees.

The larger hotel chains traditionally have several 
department heads and assistant managers to coordinate hotel operations. The smaller hotel properties may have only one or two managers overseeing the entire operation. Consequently these smaller property managers have a much greater responsibility to guests and employees in effectively implementing a risk prevention safety and security program.

There is no question that when a hotel manager is well versed in the fundemental concepts of risk prevention safety and security and how it relates to the major problem areas of hotel operations, the likelihood of a situation getting out of hand in one of these areas is greatly reduced. Furthermore, when a solution to a problem involving safety and security can be reached quickly it can mean the savings of agreat deal of time and money. Many articles have been written about the design of an effective risk prevention safety and security program. Unfortunately the majority of these articles have been written with the larger hotel chains in mind. Additinally, theses articles only report what is happenining around the industry pertaining to the major problem areas of hotel operations.

Because of this surge in litigation in recent years against hotel properties, management must better educate all levels of management in a hotel operation, regardless of the property size. Implementing this risk prevention 
program into a hotel operation at all management levels provides more than reasonable care to hotel guests and employees provided this program is adhered to. While implementing this program will not necessarily mean that the hotel will avoid liability by providing a complete risk prevention safety and security program, it does show that the hotel is making an effort to provide reasonable care to its guests and employees.

An article appearing in the November 1982 issue of Trial Magazine by Harry Philo states that "...liability is the hammer shaping a safer society... and any risk of injury or death is always unacceptable if reasonable prevention methods would have eliminated or minimized the risk."

Consequently, proof that a hotel, especially a smaller hotel property, practices within its operations a proper risk prevention safety and security program addressing the major problem areas of hotel operations as reviewed in this thesis, will place the hotel above the standard of reasonable care. Implementing and practicing this style of management where risk prevention safety an security procedures are a major part of managements responsibility reduces proportionately the liability a hotel would face in the event of Iitigation being brought against the hotel. 


\section{SECTION I}

Footnotes

${ }^{1}$ James C. Cristy, property and Liability Insurance Handbook, "The Fundamentals of Risk Management, chapter 26 (Chicago, IL: Richard D. Irwin Publishors, Inc., 1974), p. 1065 .

${ }^{2}$ William Prosser, Florida Statutes Annotated, Section 1972, 509.241, "Trade Commerce Investments," (West Publishing $\mathrm{Co} .$, ), p. 190.

${ }^{3}$ William Prosser, Law of Torts (West Publishing Co., $1980)$, p. 562 .

${ }^{4}$ Ibid, P. 561. 
SECTION II

THE REVIEW OF THE RELATED LITERATURE 


\section{SECTION II. THE REVIEW OF THE RELATED LITERATURE \\ A. The Historical Perspective}

Introduction

A hotel is a business run for profit while generally providing lodging and food facilities for its patrons. Today's hotels with vast atriums and skyscraper height's are a far cry from the facilities offered to the first users of overnight accomadations. However, it is of an interesting note that the majority of lodging properties throughout the United States are facilities with less than 100 rooms.

Because a hotel is an integral component of our society, the problems that society faces are consequently faced by the hotel in that society. Traditionally, our country has been littered with the exploits of many villians and criminals all who eventually end up utilizing some lodging facility somewhere to rest for a period of time. These individuals have historically been associated with the hospitality industry since the country was first founded. Stories of murders taking place in lodging fäcilities and other crimes are matters of police record in every major city. This goes back beyond medieval times in England even. 
there have been problems in one capacity or another associated with the industry. In the $1980^{\prime} \mathrm{s}$ it is still the same. The English Inn

The protection of people and property has been a time honored task that our organized society has pursued since the beginning of creation.

The primitive cave dwellers of past found considerable safety in banding together and living in caves. Eventually this type of housing gave way to the building of structures in which to take up residence. Homes were built, villages started and for protection walls and canals were built around these villages for protection.

Much of what we know about the history of lodging is derived from British archeological digs in various areas of the British Isles, primaxily England.

We know that the first lodging facilities undoubtedly were the spare rooms and barns of these homes in the various villages located around the British isles. 1 While these rooms may not have provided the guest with all the comforts of their own homes, they did provide shelter from the elements and protection from the criminals roaming the countryside. The first published accounts of traveling and staying at a lodging facility were recorded in 1563 by William Harrison. Harrison was a noted clergyman, topographer and chronologist living in England. His book "The Chronicles of England, Ireland and Scotland" details his travels throughout 
those countries. It notes that while Mr. Harrison had a high regard for most Innkeepers he met, he disliked their staffs. In the book he refers to these individuals as "...theives lying in wait." 2

The one particular staff member that incurred Harrison's wrath was the ostler. The rip-offs these scoundrels perpetrated on guests at these inns included the shorting of rations for guests' horses, charging for services not rendered and pilfering guests' baggage.

other staff members included the chambermaids. These individuals notes Harrison, had an affinity for rearranging the baggage in guest rooms. Of course this took place when the guests were not in the room. Harrison returned to his room on several occasions at various inns to find his valuables missing. 3

Harrison comments further on the "theiving and conspiring barmen and waitresses" he encountered while traveling. He mentions one particular criminal method used by these staff members involving themselves and a highwayman.

Because traveling in medieval England was difficult and dangerous, traveling after sunset was foolish. Travelers would take refuge in the evening at these inns across the countryside. Many travelers carried large sums of cash and other valuables with them. It was because of that fact that the plan set-up by the barmen, waitress and highwayman worked so well. 
A tired and hungry traveler would arrive at the inn looking for a nights lodging and for a meal. After setting in the room for the evening the next step for the traveler was to eat. The waitresses would supply ample food and the barman would supply ample spirits.

Over a drunken feast many travelers would speak of their wealth and travel plans. The crooked inn staff would seize this opportunity to provide the guest with directions to their destination. The plan had begun.

The next step in this conspiracy would be to contact the third part of this conspiracy, the highwayman, and point out to them their victim. An ambush would be set-up for the traveler. The unsuspecting traveler thinking that the staff had provided him with the correct travel directions never susspecting a thing.

If the traveler were lucky enough to live through the ambush and robbery, they were usually to disoriented to seek help. Many times as is the case today, these robberys went unreported. If the traveler were lucky enough to find help, groups of citizens along with a police constable would form posses to track down the criminal highwayman. However the staff at the inn would make a deal with the highwayman to use the inn as a hideout until the heat was off being tracked down. 5 After hiding out for several days the conspiracy would begin again with a new victim.

Harrison notes in his book that while most waitresses he 
encountered on his travels were clean and wholesome, he did find that there was always an exception to the rule. "During a stay at this one inn" he explains, "the service was particularly bad, the nasty dirty wenches were watching us, picking their nails, blowing their noses on their aprons and then wiping the glasses and silverware with the apron." As if this were not enough to make you sick, the waitresses at this inn then demanded gratuity for service rendered.

One of the most interesting notes made by Harrison, concerned the lack of knowledge about local and regional areas around the inn that the staff seemed to have little knowledge of on many occasions. Harrison would ask for directions to a particular destination only to be answered incorrectly or not at all.

Carl Moritz, another noted English traveler, spent several years traveling in England. He too, made mention of about his encounters with the staffs at the various inns he had visited. He summed up his true feelings about the inn staffs by saying "... at most inns I was never sure of my welcome and often feared for my personal safety..." 6

While the guests may have felt unsafe at these inns where they were lodging, the innkeeper had his share of problems also. This particular problem dealt with access control onto a lodging facility's hunting preserve.

The Horses Head Inn was renowned for the excellent hunting and game preserve that was there for the guests use. 
Unfortunately, because of its plentiful game, many poachers and other trespassers would come onto the land to hunt without permission. Ordinary fences did not keep these people out. Managements solution to the problem came from the method used by the King of England at the time, on his game preserves. It required the use of oversized animal traps called "man-traps" to be used throughout the game preserve. ${ }^{7}$ These traps were strong enough to crush a man's leg to the bone when it was stepped on. As interesting as the story was, no mention was made as to how guests would avoid these traps, nor if any liability arose from their use.

Another unusual problem facing the English Inn during medieval times was the falling of inn signs onto pedestrians walking on the street below them. In England during the early $1700^{\prime}$ 's it was common practice to hang the inns name on a wooden frame, and suspend the sign using a metal cable over the street below. As the inns became more competative, the signs became larger and heavier. While the cables supporting the signs could support the weight, the fastenings in the walls of the various buildings could not. These moorings would give way and the signs would crash to the street below. Several people were killed and others seriously injured because of this.

In 1718 several local town goverments enacted bans that prohibited the hanging of signs over any public street in the community. 
Inkeepers then decided to attach the inn names directly to the walls of the buildings. However, the signs still fell because of their weight.

Finally in 1797, during the reign of king George III, all signs hanging over public sidewalks and streets were banned. It took goverment intervention at a national level to intervene with the inn owners to find a solution. 9

The eventual solution to this problem was to place the signs atop poles placed deep into the ground to support these very heavy forms of advertising. This worked so well that many signs are still standing today.

Goverment intervention made its presence felt early in England in order to require the inkeepers to provide adequate safety and security for guests and visitors to the inns. King Edward VI in 1537 made the operation of an inn or tavern without a license against the law. ${ }^{10}$ This licensing enactment imposed goverment decreed standards on the Inn's. Because no standards existed prior to the licensing enactment, many individuals were becoming ill from eating and drinking at these establishments.

Punishments varied for not having a license and included heavy fines and even being placed in the town dunking pool. 1

The American Inn

Stories about American Inns are filled with many of the same accounts of criminal wrongdoing. Their history is short compared to the English inns, they have stories of being 
associated more with being the meeing places for political activity more than accommadstiond for food and sleep.

For all practical purposes the first American inn was the Mayflower. With the landing of the Pilgrims at Plymouth Rock in 1620 it was the only shelter available to them so they lived on board. The charter company, which owned the ship, provided food for these early settlers while living aboard the Mayflower.

As the country began to grow, the families of the first settlers provided food and shelter to these later settlers. Soon it was realized that a comfortable living could be made from providing lodging to these settlers. Many of the first inn owners were preachers, parsons and retired army officiers from the English army. 12

The first documented publication about life of the American innkeeper was written by Edward Fields. The book "The Colonial Inn", spoke about the tremendous hospitality he encountered at these first American inns. The biggest problem these ownexs faced was the theft of services by customers, especially from the military officiers from the English army that frequented these inns. This is one reason why early inn owners were so open to letting the colony revolutionaries use their properties to hold meetings on how to overthrow the English goverment ruling the colonies.

The Green Dragon Inn located in Boston was the secret headquarters for the "Whig Party." The Whig Party was 
composed of American colonists who supported independence from British rule.

As far as goverment intervention with the first American inns, this was left up to the local town councils. Most licenses were issued to innkeepers under the following guidelines: 14

1) Guests must be served with wholesome and plentiful food.

2) Beer, wine and spirits must be good and unadulterated.

3) Rooms, beds, windows, crockery and silver must be kept clean and in good condition.

4) Guests must be treated with kindness and cordiality, but the guest must not be encouraged to be intemperate or to run themselves into debt. This was the beginning of the first Dram Shop Act.

While these guidelines were to be strictly adhered to, there appears to be a lack of guidelines addressing safety and security. Besides guest theft, fire was a major problem concerning the first innkeepers. No fire codes existed to prevent serious injury occurring to guests at an inn in the event of a fire.

Public outrage addressing fire protection reached a climax after the New York fire of 1835.15 Over 700 buildings were destroyed and 35 million dollars in damage occurred due to a lax fire code in the city. To try and prevent this from reoccurring, a plan was devised by local goverment to divide the 
the city into fire districts. Each district woul have its own fire department. On the department property located at each district fire station would be a tall observation tower overlooking the district. Upon the discovery of smoke or flames a fire brigade would be sent out to find the fire, which it did not always do. Many times a home or building would burn down before the brigade arrived.

Samuel Morse's invention of the telegraph in 1844 was a big help for the fighting of fires as well as a great benefit to society in general.

Through the use of the telegraph a fire could be immediately pinpointed in a district. However this system was not without fault. The Grat Chicago Fire of 1871 caused an estimated 700 million dollars worth of damage to property and killed in excess of 300 people. The fire which allegedly started in a barninside the city was pinpointed by an alert fire marshal from the districr observation tower. However, for reasons unknown, the wrong fire department was contacted to put out the fire. ${ }^{16}$ By the time the proper districts were notified the fire had spread to several buildings. Compounding all this was a dry summer in Chicago with no rain and human error bordering stupidity.

\section{B. Understanding Hospitality Law}

The more sophisticated a society becomes, the more complex and complete its laws become. One particular area of hospitality law that is creating a legal nightmare for innkeepers is 
the area of legal liability. The term most commonly associated with liability is "reasonable care." When a situation arises and liability is involved a question of reasonable care is asked.

Unfortunately for the hospitality industry, not only is the general public concerned with liability but also the State and Federal Goverments. For example the recent introduction of the Dram Shop Act that have been enacted by legislatures of many state govermentshave placed trmendous liability on the nations hotels and restaurants. Essentially this law allows for the recovery of damages against establishments that serve liquor to intoxicated persons, and as a result of that intoxification injure a third party, that establishment is liable.

With the above in mind let us seek to define hospitality law. Hospitality laws are the areas of civil and common law that focus on the rights and remedies of groups or individuals, who by some manner, whether as a first or third party, are using a lodging or eating establishment in one form or another. Additionally it involves the rights and remedies of people against supplier whose services have been contracted for or that can be reasonably expected for to be delivered as contracted for.

Typical litigation involves suits pertaining to physical harm, theft of belongings, overbooking, misrepresentation and tortious conduct by hotel staff.

The lawsuit lottery against hotels began in earnest in 
the late 1970's with the "Connie Francis Case." Attorneys for the plaintiff, Connie Francis proved that the hotel in question had not used reasonable care consequently making them liable for punitive damages. The hotel had not checked a faulty door locking mechanism on a sliding glass door. This led to a rape occurring on Connie Francis and cost the hotel several milition dollars.

A suit against Holiday Inn involved a breach of contract filed against the hotel. Holiday Inns advertises that when checking into their hotels a guest would receive "no surprises." The guest upon checking into the hotel room was robbed at gunpoint. The guest was "surprised" at being robbed and subsequently brought litigation against the hotel for a breach of contract. He won his suit on the ground that being robbed at the hotel was a "surprise" when the hotel had contractually promised "no surprises." 19

Annually the national crime rate increases in the united states. As a result of these higher crime statistics many business organizations are tightening security provided for their customers. This especially true in high crime areas. Ironically this increase in security has reduced the number of criminal attacks on businesses,-but has increased the number of lawsuits against businesses. ${ }^{20}$ The main reason this occurs is because providing security shows recognition by a business that security is necessary. If this security is inadequately provided then the business is liable, if it is not properly 
implemented within that business.

The law is very clear about the duty owed to the guest using a lodging establishment. Basically the law states that "reasonable care" must be excercised when dealing with hotel patrons and in providing the necessary safety and security to protect that patron. The specific duty owed to a guest will vary according to the size of a hotel, but reasonable care is self-explanatory. Consequently, in hospitality law, a hotel must excercise reasonable care in the handling of its guests.

C. An Overview of Hotel Safety and Security Today Many books and articles have been written about the area of providing quality safety and security to the patrons utilizing lodging establishments. Few of these books address the smaller hotel properties and how they need to handle this area. Consequently many of these smaller properties utilize non-hospitality type methods to provide safety and security for guests. For example, in some smaller properties, many of the fire exits are chained shut in the evenings to prevent thieves and unwanted trespassers out of the property. This is a very unwise practice because in the event of a fire or other disaster there simply is not enough time to go around to each exit and unchain these doors.

A hotel runs 365 days a year, 24 hours a day. This means management has a responsibility to be prepared for any event that could occur in that time frame. Recent court rulings in Washington state and the rest of the country are setting higher 
standards of care for the hotel industry. 21 This means that a higher degree of care is going to be applied to cases dealing with hospitality litigation.

Because of the labor intensive nature of the hospitality industry this task of providing a higher degree of care will. become even more difficult. However with the proper utilization of this risk prevention safety and security manual as part of all managements function in all hotels regardless of size, it shows the public that a higher degree of care is being used.

According to industry surveys most hotel managers agree that part of their job responsibility is to protect the hotel guest from any form of harm. ${ }^{22}$ This is where hotel security officers are an important element in providing proper safety and security.

Says Thomas Lisante, Director of Security at the New York Hilton, "... our officens: must be well versed in the laws of arrest, able to anticipate security problems and be personable." 23

Many security officers feel that the strongest defense in securing a hotel against crime is to have a community organization that meets on a regular basis. 24 The purpose of this would be to exchange ideas about the handling of various security problems encountered in that area of the community.

"Being able to anticipate problems before they occur is important to effective hotel safety and security." says Lisante 25 The guests' role in helping to insure their own safety is 
extremely important. All the safety and security precautions taken by the hotel are useless if the guest will not excercise a reasinable amount of common sense while staying in a hotel property.

Constant reminders regarding the guests to look after their baggage keys and other belongings can be utilized in the form of oral messages and note card reminders. Using these messages in the New York Hilton reduced crime 73 per cent according to Thomas Lisante, their Director of security. Hyatt Hotel Corporation has been an innovator in hotel safety and security. Regarding key control and the problems associated with that area of hotel operations, forced Hyatt to use what they cakk their "Passport" system. The paper folio designed to look like a passport contains the code to the room number. None of their keys have the room number on them. Consequently if a key is lost, only the guest is aware of the room number. This reduces tremendously the opportunity for a guest room to be robbed.

Employee theft is a serious problem in the hotel industry and business in general. Employees outsteal guests 5 to 1 according to an article in Club Management magazine. ${ }^{26}$ Untold millions of dollars worth of valuables leave through various hotel entrances and exits each year. The attitude of many employers is that this is the cost of doing business." 27 How can hoteliers adopt such a cavalier attitude when according to an article in U.S. News and World Report, 30 percent of all 
business failures in the United States are a result of employee theft.

David Burger, a security analyst in Los Angeles, says "Pilfering begins with small items like paper clips and pencils and simply mushroom from there." Critics have long argued that this problem has existed in all business segments. Because it is so widespread and often involves articles of small value, managers pay little interest to the problem. Consequently, this lack of interest amounts to a form of encouragement foremployees to steal from their employers.

A recent survey by the National Institute of Justice by sociologists John P. Clark and Richard Hollinger reported these findings:

1. Over one third of employees polled in all segments of business admitted stealing from their employer.

2. Top level management is involved in employee theft. 3. Most employees donot regard stealing from employers as an act of theft.

4. Proper screening of employees will effectively reduce the problems of employee theft. Checking employee references is a must.

Dr. Howard Schawrtz, an industry security consultant feels that one of the most cost effective methods of controling employee theft is to provide a good work environment and show the employees that you really care about them. This is most important to provide quality work 
conditions and to supervise your employees with equal fairness.

The major reason employers do not press charges against employees is due to time and the cost of litigation. Employers who do press charges are attacked as being unfair and discriminatory in proceeding with such actions.

While treating employees fairly is not the final solution to ending employee theft, it is certainly an effective deterrent.

"One method of showing employees you care is by developing a comprehensive safety and security plan for the hotel," 28 says Albert A. Seedman, a security consultant. Showing employees that you are concerned for their welfare, as well as the guests, is beneficial to everyone involved in the hotel. People are basically honest and tend to remain so if they feel that they are working for a concerned and caring business organization.

When developing this comprehensive safety and security plan, the area that must not be overlooked is lighting. With the smaller hotels this is especially important. Due to the lack of manpower, an excellent deterrent for crime is the use of lighting. Having an understanding of the various types of lighting systems can help determine your specific needs.

Harvey Burnstein, a former corporate director of security at sheraton, feels that too much time is being 
spent trying to apprehend and prosecute the petty criminals. "We need to deal with the causes rather than the effects," says Mr. Burnstein. This is very true, for example, it does not matter how sophisticated a room lock on the guest's door is if the hotel has an inadequate key control system. Likewise, it is futile to provide a secure room door lock, but have inadequate and easily compromised windows and sliding glass doors in the same room. Smaller hotels, because of theix vulnarability, should be very aware of guest room security. While resources and manpower may be limited at the smaller properties, having the management and staff aware of the need for hotel safety and security is a step in the right direction.

Implementing within the management and staff the need for safety and security begins from the first day of employment. Checking up on a potential employee's references initializes the employee that the hotel is doing its job. While checking references is time consuming, it is very beneficial. "While cost may be a factor to limit screening, litigation from employment practices has caused companies not to check up on references," 29 says Marshall Mayer in a recent issue of Security Management. Statistics compiled by the Department of Commerce indicate that 30 percent of all business failures are a result of the dishonest acts of employees. Consequently, today a business cannot afford not to check references. This seems to be the current trend. 
Other personnel practices that are gaining popularity include "Interviewing by objective." 30 This management tool utilizes the concept of objectivity in an interview rather than an interviewer's subjectivity. The problem with an interviewer's subjectivity is that they may be fooled by a first impression or be overwhelmed with an applicant's credentials, for example. Dr. Larry Hormon, a Coconut Grove psychologist and expert in this field, explained that this method of interviewing applicants involves determining "structured situational questions." 31 In other words, the questions asked are scenerios which require the applicant to work through a problem. Points are scored by how well the applicant answers the question. While no system of interviewing is foolproof this interviewing by objective offers greater insight into an applicant's reasoning skills.

The concern for guest and employee safety cannot be overlooked when developing a comprehensive safety and security plan today. Probably the most cost effective method of determining the adequacy of hotel safety regardless of size is the monthly inspection of the property. By reviewing all areas of the property from top to bottom an idea of how safe the hotel is can be ascertained. Problems can be taken care of before they become worse. "The biggest problems are not the hazards but the people," says Jim Moyer, Marriott's Director of Loss Prevention. ${ }^{32}$ Marriott was besieged with accidents during the early 1970's. As a 
result of this, the company began a program to decrease this situation. The country was divided into seven geographic areas, each area had a Loss Prevention Director. Their job is to review each Marriott property located within that geographic region eight times a year to check for safety problems. The result has been a substantial decrease in the number of accidents involving employees.

The Boston Sheraton experienced a similar problem with employee accidents in the late $1970^{\prime} \mathrm{s}$. Slip and fall injuries were a common occurrence of this particular property. To combat this problem employees were issued safety shoes with non-skid soles as part of their uniform. This greatly reduced the number of accidents caused by employees slipping on the hotel floors.

The consensus among most professionals within the hotel industry is that employees generally adopt the philosophy of management regarding safety matters. Once again, by showing that you care, an employee is less likely to take advantage of an opportunity to stay home from work. 33

The last area that a comprehensive safety and security plan needs to detail is the handling of emergency situations. The trend today is to train employees to speak to a manager anytime a situation involving an emergency occurs. At employee meetings, reviewing the handling of various emergency situations is a good management practice. Documentation that employees are trained or at least aware of 
emergency procedures is absolutely necessary should litigation be brought against a hotel property. The one area of emergency planning that should be clearly defined is the handling of fire. Specific responsibilities must be assigned to various hotel staff members. ${ }^{34}$ In the event of a fire, time is the biggest enemy. Being able to evacuate the guests by contacting them as soon as a fire is discovered is essential in the prevention of a potential catastrophe.

\section{The Future of Risk Management Safety and Security}

Hotels are placed in an unusual dilemma. They serve not only their lodging patrons but also the rest of the general public--known as third parties. While the hotel may be considered quasi-public legally, anyone who feels wronged while visiting the hotel can seek litigation against the property for any number of reasons. The grounds for most litigation can be traced back to a failure to provide adequate safety and security at the hotel.

"Unfortunately, only the courts know exactly what adequate security is and they don't tell you in advance, "35 reports Lawrence W. Sherman, an Associated Professor of Criminology at the University of Maryland at College Park, and Director of the Security Law Institute. What this dilemma leads to is an extremely volatile situation doing business with the public. What the courts are basically saying to American businesses is that you must place a 
security system within your business. Now whether or not it's any good will be decided after there has been a breach of security. This sounds confusing because the whole purpose of providing security to a business is to prevent breaches of security from occurring in the first place. This is most evident in the hospitality industry with guests lives involved.

To circumvent this traditional attitude taken by the American Judicial System, Sherman asks that security professionals in this country propose legislative action that would set specific standards for specific businesses in specific areas of the country.

These standards would be utilized by all businesses across the country as guidelines as to whether adequate security is being provided. This would be similar to say fire codes that are manadatory in businesses across the country.

These standards would carry the force of "expert opinion" on a national basis should a business become involved in a lawsuit involving say a breach of security. These standards would then be introduced to the court and depending on the type of business, the company's security standards could be matched against the national standards. In this way a clear cut answer as to who is at fault in such a matter can be determined and to see if reasonable care was used.

Currently, standards of security are being developed by the Security Law Institute in washington, D.C. The 
committee has a special unit developing standards for the hospitality industry.

The current methods being used to determine how these standards will be developed are simply through the debating process. Each security standards committee meets, discusses issues, analyzes the issues national implications and then forms fundemental agreements that eventually will become a national standard.

Sherman feels that while this litigation explosion is here to stay, this developing of security standards is a step in the right direction. Unfortunately the question remains, would these standards become the "reasonable care" standard which a hotel property must meet? Not necessarily so. It could lull the innkeepers into a false sense of security. By meeting these standards set by the Security Law Institute, innkeepers could meet the standards set and not be required to do anymore to a property, when in actual fact a property may requre additional security due to special circumstances. The debate will continue.

Currently breaches of safety and security are based on two elements. Firstly was a situation foreseeable and secondly, was reasonable care taken to prevent a foreseeable situation. The point at whether a situation was foreseeable and if the situation had excercised reasonable care varies from state to state and jury to jury. A Florida case involving this element of foreseeableness involves werndilli vs. Greyhound Bus, Inc. 36 
A bus traveler waiting for a Greyhound bus to take him to his destination was mugged and robbed. However, he was not robbed and mugged at the Greyhound Bus Terminal, rather it was in a phone booth across the street from the terminal. The reason that Mr. Werndili became a victim was because of the high crime area in which the bus terminal is located. The defendant claims that Greyhound Bus Terminal owed him the duty of warning him about the high crime in the area. The initial court decision was that Greyhound owed no duty to warn the defendant about the crime in the area and that the area was not in a high crime zone. The judge ruled on this case as a matter of Law.

The case was appealed. On appeal, it was overturned and answered with this statement by the higher court, "As to whether or not a crime is foreseeable is a question for a jury to decide. . and not a matter of law for a judge to interpret. . . . "37

Another case involving foreseeableness is the New York case of Stevens vs. Kirby. The defendant won a judgment from the plaintiff based on the element of a situation being foreseeable.

The defendant was assaulted in the plaintiff's bar parking lot. Several other fights had occurred in this parking lot over a period of several months.

on appeal, the case was overturned based on the following answer by the higher court ". . even though the police 
broke up the fights, they did not actually witness them, therefore, evidence admitted by them was hearsay and not admissable. . . . "38

Because of the diversity of the courts ruling on these type of breaches of safety and security, Sherman demands that standards be set. Otherwise, all businesses and industries will be at the mercy of the American Judicial system.

The developing of standards would ultimately assist companies in developing specific security methods for specific type of situations.

A critic of the idea by developing safety and security standards is security consultant Harvey Burnstein. Mr. Burnstein, a former Corporate Director of Security at Sheraton, feels that hotels are too unique an entity to propose and integrate a uniform set of standards by which to follow.

What is necessary are guidelines which are voluntary, thus allowing the property owners maximum flexibility to adopt guidelines best suited for their property.

Burnstein warns that if industry chooses to neglect its responsibilities of proper security that governmental intervention and mandatory standards could eventually be the outcome.

This is precisely what happened to the auto industry. Their refusal to acknowledge health and safety violations caused congress to establish standards that a Government 
Regulatory Agency oversees.

This is not to say that the hospitality industry has neglected its duty in providing proper guest-employee safety and security. What is being said is that if the industry fails to protect the guests and employees in the hospitality industry then goverment intervention may end up being the solution.

\section{E. Summary}

In reviewing the related literature it becomes apparent that the five major problem areas historically plaguing the the hospitality industry are general hotel safety and security, personnel, lock and key control, lighting and fire protection. Admittedly, these problem areas are an inherent part of the industry. However, continued failure by the industry to effectively adaress these problems as part of an overall management function will eventually lead to increased litigation, increased goverment intervention and lost business.

This intervention began in the 1500 's with the forced licensing of lodging establishments by the King of England. Intervention today takes the form of the Dram Shop Act in the United States.

Because of this a muchrreeded reemphasis on risk prevention safety and security as part of a management function is needed. While this offers no concrete solution to these five major problem areas in the hospitality industry, it is a step in the right direction to providing reasonable care to guests and employees. 


\section{SECTION II}

Footnotes

$1_{\text {Thomas Burke, The English Inn (London: Butler Tannon }}$ Limited, 1947), p. 3 .

${ }^{2}$ Ibid, p. 60 .

${ }^{3}$ Ibid, p. 61 .

${ }^{4}$ Ibid, p. 62.

${ }^{5}$ Ibid, p. 63.

${ }^{6}$ Ibid, p. 49.

${ }^{7}$ Eric Delderfield, British Inn Signs and Stories (London: David and Charles Publishers, 1972), p. 134.

${ }^{8}$ Ibid, p. 140 .

9 Henry Parr Maskell, The Taverns of old England (London: John Day Publishers, 1977) . p. 134.

${ }^{10}$ Ibid, p. 70 .

${ }^{11}$ Ibid, p. 50 .

12 Elise Lathrop, Early American Inns and Taverns (New York: Benjiman Bloom, Inc., 1968), p. 60 .

${ }^{13}$ Ibid, pp. 226-227.

14 Ibid, p. 160.

15 William Bridgewater, The Columbia Encyclopedia (New York: Columbia University press, 1968), p. 398. 
16 Herman Kogan, The Great Fire: Chicago 1871 (New York: G. P. Putnam \& Sons, 1971), p. 54.

17 Norman G. Cournoyer, Hotel Restaurants and Travel Law (Mass.: Breton Publishers, 1983), p. 507.

18 Thomas Dickerson, "Securing Travelers Rights and Remedies," Trial, August, 1982, p. 44.

19 "Safety Questions at Holiday Inn," Newsweek, July 27, 1981, p. 59.

${ }^{20}$ Donald Schultz, Security Litigation and Related Matters (Chicago: Charles Thomas Publishers, 1982), p. 10.

${ }^{21}$ M. Krakowieki, "Hotels Heap Heavy Dollars on Heavy Risks," Business Insurance, October 20, 1975, pp. 19-22.

22 Styllianoss Irini, "Doing Security work: Keeping order in the Hotel setting," Canadian Journal of Criminology, Robert Publishing Company, 1980, p. 63.

23 Thomas Lisante, "Improving Hotel Security," The Cornell HRA Quarterly, May, 1976.

${ }^{24}$ Ibid, p. 8 .

${ }^{25}$ Ibid, p. 9.

${ }^{26} \mathrm{Dr}$. Howard Schwartz, Club Management Magazine, February, 1982, p. 93.

p. 79. ${ }^{27}$ U.S. News and World Report, September 26, 1983,

${ }^{28}$ Lawrence J. Fennelly, The Handbook of Loss Prevention and Crime Prevention, p. 634.

${ }^{29}$ Marshall M. Meyer, C.P.P., Checking References: It's Worth the Investment, March, 1983.

${ }^{30}$ Bruce Jones, Florida Trend, p. 99. 


\section{SECTION III}

THE DEVELOPMENT OF THE RISK PREVENTION SAFETY AND SECURITY MANUAL 
${ }^{31}$ Ibid, p. 100

${ }^{32}$ Leslie stackel, Hotel and Resort Industry, December, 1981, p. 65.

${ }^{33}$ Lynn Thomas, Pacific Restaurant Magazines, May, 1982, p. 26 .

${ }^{34}$ William F. Parks, Security Management, July, 1980, p. 86 .

${ }^{35}$ Lawrence W. Sherman, Security Management, p. 25.

${ }^{36}$ D. F. Werndili vs. Greyhound Bus Lines, Inc., District Court of Appeals for the Second District, Florida, 1982.

37 Ibid, p. 36 .

${ }^{38}$ Stevens vs. Kirby, No. 273, 1982, New York State Supreme Court, Appellate Division, May 14, 1982. 
SECTION III. THE DEVELOPMENT OF THE RISK PREVENTION SAFETY AND SECURITY MANUAL

\section{Introduction}

Risk management safety and security is a concept that consolidates the major problem areas of hotel operations. It is primarily composed of five units:

1. General Hotel Safety and Security Program

2. Personnel

3. Key Control

4. Lighting

5. Fire

The fundamental idea behind this management concept is to offer hotel managers at any level a more complete understanding in effectively operating a safe and secure hotel property. Furthermore, the concept designed with the smaller hotel in mind where safety and security is more of a management function.

The term Risk Management originated in the early 1960's, and is most often associated with the insurance industry. It is defined as "the seeking of economical methods to control risk of accidental loss where insurance is the last resort rather than the first." ${ }^{1}$ Traditionally this term was Iimited to insurable risks. The modern definition of risk management as it applies to the hotel industry is ". . the anticipation, recognition and appraisal of a risk and the 
initiation of some action to remove the risk or reduce the potential for loss to an acceptable level. "2

This definition by the National Crime Prevention Institute is an appropriate summation of risk management safety and security. It should be pointed out that the four sections of this study involve five different levels of risk.

The first level of risk management safety and security is Risk Avoidance. This level involves the complete elimination of a safety and security problem. A simple example would be a tear in a carpet being fixed so people won't trip over the carpet.

The second level is Risk Reduction. Here we determine how low can we reduce a risk. A simple example would be a problem with guests leaving their doors partially open or forgetting to close them. To reduce this type of risk a self-closing hinge mechanism attached to the door and door frame might be a solution.

The third level involves Risk spreading. This level incorporates the use of alarm systems, closed circuit television, barrier systems, lighting systems, key control systems and other similar systems that help spread the risk. A simple example of this would be the use of effective lighting. For example, having overhead lights directly above the guest room door rather than off to one side, greater visibility is offered at night. 
The fourth level of risk management safety and security is Risk Transfer. This level involves passing the responsibility of safety and security onto others. This can be in the form of insurance premiums, hiring a private security firm to secure the hotel or hiring a management contracting company to run the hotel. These are examples of trying to reduce your own liability by placing the responsibility of running the hotel property on someone else.

The last level is Risk Acceptance. This level basically states the risks allowed will not disrupt the business. Tis level is considered a last resort. A simple example would be a hotel located in a high crime area. If after exhausting the first four levels of risk management safety and security, the fifth level, Risk Acceptance, must be considered. However, any hotel that is operating with a high degree of Risk Acceptance within its management will most likely be out of business very shortly.

It is important to understand that this study will primarily involve only the first three levels of risk management safety and security. Risk Transfer, and Risk Acceptance are geared towards tolerating certain risks. Risk Avoidance, Risk Reduction and Risk Spreading are levels that try to find acceptable solutions to specific risks.

Each of these levels is administered to each major problem area within the hotel operation. This is done through a hotel operation inspection and analysis. However, 
before this inspection and analysis can be administered, a complete understanding of each problem area is needed. The next five sections offer insight into these areas and possible solutions in handing these problem areas. These areas are as follows:

-General Hotel Safety and Security Analysis

-Personnel

-Key Control

-Lighting

-Fire Prevention

A. The General Hotel Safety and Security Program This unit is designed to give the hotel manager a greater insight towards the current safety and security of the hotel operation. This is accomplished by touring the interior and exterior of the hotel property regularly. When a safety or security problem is found, diminishing it to an acceptable risk level is the solution. As the smaller hotel manager becomes more aware of the characteristics of the particular property an anticipatory attitude should be developed in handing hotel problems affecting safety and security.

The analysis of the hotel is composed of three areas. They are as follows:

1. Property Characteristics

2. Access Control

3. Employee Awareness 


\section{Property Characteristics}

This area of the general hotel safety and security analysis begins with a historical overview of the particular type of community environment in which the hotel operates. Past crime statistics from the hotel as well as the local police force will help in determining consistent problems it faces. Knowing these particular problem areas is the first step in understanding a property's particular characteristics. These characteristics will determine the risk envixonment the hotel is currently situated in so that a risk prevention program can be formulated. The next step is to determine if the hotel is operating legally according to city and state regulations such as the fire codes, building codes and licensing codes. This is extremely important. In the event of litigation against a hotel property, failure to comply with city and state regulations is a form of negligence.

The next step in understanding property characteristics is to develop a checklist for touring the hotel property. Potential risks on the property can be looked for so that preventative measures can be implemented. Below is a possible list of questions that can be utilized in developing the area of a property characteristics program:

1. Who is responsible for touring the hotel grounds?

2. Is the property fenced?

3. Can the fence be easily manipulated? 
4. Are fence gates properly locked and secured?

5. Is protective lighting used on the property?

6. Do fire escapes comply with city and state regulations?

7. Are boxes, crates and other similar materials found around the building?

8. Have vulnerable areas been determined?

9. Are there alleyways behind the hotel that need to be illuminated?

10. Have all walking surfaces, including stairs, been treated so as to provide non-slipping conditions?

11. Are handrailings sturdy and supportive?

12. Is signage used to alert both employees and guests of potentially dangerous situations at the hotel? Are these signs visible?

13. Are entrances and exits on the hotel property illuminated with sufficient light?

\section{Access Control}

This area of the general hotel safety and security analysis covers all possible entrances and exits on the hotel property. This includes all doors and windows as well as entrances and exits in the hotel buildings. The effective controlling of this area is most important. The majority of litigation facing hotel properties today involves several areas of access control. These include poor 
lighting at vulnerable points on the hotel property, poor or non-existent key control of guest rooms and weak or ineffective locks on guest room doors.

Access control became the most important issue in 1976 . In Garzilli vs. Howard Johnson Motor Lodge, ${ }^{3}$ the prosecution rested its case upon the fact that the hotel had a faulty sliding glass door locking mechanism. The case was just the beginning in litigation against hotel properties failing to implement access control procedures in their operations.

Below is a possible list of questions that can be utilized in developing the area of an access control program.

1. Are all door frames made of a strong material?

2. Are doors easily opened and closed?

3. Are self-closing door mechanisms in good working order?

4. Are door hinges easily manipulated?

5. Do guest room doors have $180^{\circ}$ peephole viewers in them?

6. Is panic type hardware used on fire doors?

7. Is proper signage being utilized showing entrances and exits in the building?

8. Are door locks in good working order?

9. Are the strikes within the door frame in good working order?

10. Are unused doors properly secured?

11. Are exits free of obstructions and readily accessible? 
12. Do doors show signs of forced entry?

13. Have sliding glass doors been secured with specialized locking devices?

14. Are entrances and exits properly illuminated at night?

15. When were locks last changed on guest room doors?

16. Are door locks UL approved?

17. Are guest room door locks protected from prying and jimmying?

18. Are keys used in the hotel operation devoid of identification?

19. Are spare keys of the manufactured style or just any old style any locksmith could duplicate?

20. Can all windows on the hotel property be locked?

21. Have non-essential windows been properly secured?

22. Are windows in guest rooms covered with protective screening of some type? (with quick release hinge)

23. Have jalousie type windows been removed and replaced with more secure type windows?

24. Are window frams solid and in good repair?

25. Have window locks been checked recently to insure they are in good working order?

26. Have security windows in more vulnerable areas been utilized?

27. Have any windows been reinforced with lexan?

28. Have full length windows been marked to prevent accidental injury? 


\section{Employee Awareness}

This area places greater responsibility on the employee in providing a safe and secure hotel environment. The majority of hotel employees work in the back of the house operations. Consequently, they have a greater visibility of the hotel property. The employee should be made a part of the hotel "family" with a major role in risk prevention.

These employees must be trained properly in order to recognize and be able to anticipate possible risks. These risks many times involve the safety and security of the employee. Consequently, not only do hotel guests benefit from a hotel safety and security program, but also employees. Below is a list of possible questions that can be utilized in developing the area of employee awareness.

Housekeeping

1. Are metal wastebaskets used in all guest rooms?

2. Is the guest room free from all tripping conditions?

3. Do the maid carts have any valuables on them?

4. Are maid carts used to block entry into a guest room?

5. Has all electrical wiring been checked for fraying?

6. Are electrical cabinets kept locked?

7. Are non-flammable and non-toxic cleaning fluids used?

8. Are all bathroom surfaces, especially the bathtub, covered with a non-slip surface? 
9. Are public restrooms inspected and sanitized regularly?

10. Does the housekeeping staff know where all emergency shut off valves are located?

11. Are problems such as burned out bulbs noted as the rooms are cleaned?

12. Are storage areas properly ventilated?

13. Are storage closets neat and organized?

14. Do rooms come with personal safes?

15. How often is machinery (vacuum cleaners, carpet cleaners, etc.) used in housekeeping checked?

16. Have policies been determined for mislaid property?

Pool Review

The major problems with hotel swimming pools are the pumps, filters and piping. Because of the tremendous use that the pool incurs the likelihood of a problem occurring when the guests are using it is highly probable.

The hotel pool is open to all hotel guests, normally. This includes the guests with highly infectious or contagious diseases. No one can tell them not to swim in the hotel pool but their own conscience.

1. Is lifesaving equipment accessible in the immediate pool area? 
2. Is the pool area closed and locked during hours of non-operation?

3. Are signs visibly posted with instructions on the use of the pool?

4. Is the pool cleaned daily? Is the water level checked on a regular basis?

5. Is a daily water purity test conducted?

6. How often is the pool filter and related machinery checked?

7. Are depth markers and cautionary signs clearly legible?

\section{Routine Safety Rules}

1. When doing a hazardous job are protective procedures and devices implemented?

2. Are objects that require pulling rather pushing properly noted?

3: Does the job reqire an unusual amount of physical support?

4. Analyze a job before beginning it?

5. Use the proper tool for the proper job.

6. Use leverage when possible.

7. Avoid lifting on a slippery surface.

8. When lifting, keep items close to the body.

9. Have a secure grip when lifting any object.

10. Donot change a grip while lifting an object.

11. Avoid walking backwards when carrying objects. 
13. Do not rotate your body while lifting.

14. Long objects should be carried by two people.

15. Carry mops and brooms vertically.

16. When cleaning stairs never leave items on steps.

17. Always apply force away from the body.

18. Never reach into a garbage can.

19. Avoid pulling wiring, use the plug.

20. Use plastic containers whenever possible to store Iiquids.

21. Natural soaps leave a slippery film. Do not use them.

22. Make sure the proper signate is used when dealing with flammable and toxic cleaners.

\section{B. Personnel}

Introduction

One of the most important areas of any business organization is personnel. The hotel industry especially must place special emphasis in this area. Without question this is a major problem area for a hotel operation regardless of size.

This area of hotel operations is where potential hotel employees are introduced to management for the first time. The impression an applicant perceives from management during an interview is extremely important. For example, if management shows an attitude that indicates they will hire 
anyone for a particular job in the hotel, the applicant most likely will perceive this negative manner.

Should management interview the applicant with a structured questionnaire, reference checking and supply job descriptions for the applicant, a positive image is formed in the applicants mind.

Having a well organized personnel department, regardless of the property size, is a hotel manager's responsibility and is an essential element to the risk prevention safety and security program.

The Development of an Effective Personnel Program

There are four fundemental procedures that must be understood in order to develop an effective personnel program. A general knowledge of these areas are essential in the effective operation of a hotel. These four procedures are:

1. Job Descriptions

2. Interviewing

3. Checking

4. Training

Job Descriptions. The initial step in developing an effective personnel program is to develop job descriptions. These descriptions should relate to the size of the hotel. Larger hotels will have more employees performing more specific job functions. Smaller hotels will have less job descriptions.

The smaller hotel employees will perform more 
general job descriptions. This step will take considerable time in the beginning of its inception. The long term dividends of investing that time will be well worth the effort.

The job description should be specific rather than a general format. The more specific a job description, the more indicative of the actual skills required to do that job.

Three areas must be covered in determining the job description:

Firstly, the necessary skills and abilities must be identified. An example would be the ability to lift, push, wash or clean as in the case of a room maid.

Secondly, special job knowledge needed to perform the job. Hiring a bookkeeper with no bookkeeping experience is obviously an unwise business decision.

Lastly, identifying all job tasks expected from the person in that job. An example would be making the responsibility of cleaning not only guest rooms but hallways and public bathrooms located within the hotel.

These job descriptions will prove beneficial to hotel management when the various responsibilities of who is doing what is clearly understood by both management and staff. This all adds up to a better work environment for the hotel team. Above all do not hire until you find an employee who has the skills you are looking for. ${ }^{4}$ 
Interviewing

This step involves sitting down and talking with potential job applicants. Based on the exchange of information between the interviewer and the interviewee, the question of employment is usually determined by both parties. Interviewing however, "has an apparent simplicity that is misleading," according to Edward Webster in his book, Decision Making in the Employment Interview. Invariably, the person interviewing rarely attains all the data necessary to make a totally accurate decision. Interviews should predict potential job success of job applicants. Traditionally the job interview is more of a test for the handling of stress by the job applicant. 5 Today, however, the role has somewhat changed. Todays interviewer must be well versed in current civil rights legislation, EEOC guidelines and court decisions involving employer-employee relationships.

Employment interviews should begin with several introductory comments. This serves a dual purpose, it establishes a rapport with the job applicant and helps place them at ease. once this rapport has been established the interviewermust begin the actual interview. There are several methods of interviewing. The most common is the straightforeward, face-to-face, question and answer situation. This is commonly referred to as the direct method interview. It measures several areas of the job applicants abilities, personality profile, ambition, basic job skills, job 
knowledge and personality characteristics. ${ }^{6}$

The interviewer must make sure that while using the direct interview methods that several points be kept in mind. They are to use plain language, be objective, ask open-ended questions and never show approval or disapproval. 7 It is also important that the job applicant be given the opportunity to ask questions about the specific job. The interviewer should be prepared to answer those questions. Using job description forms already designed greatly helps the interviewer and interviewee understand what a job will entail.

Excessive kindheartedness by the interviewer will generally excuse defects of an interviewee.

Industry experts all readily agree that the best interviewers are those who are cold-bloodedly objective and critical.

There are several specific traps that an interviewer can fall into while interviewing.

The first impression foul-up: Many interviewers are so impressed with an applicants appearance and resume that they forget to be objective.

The halo error: This permits one or two outstanding qualities of a job applicant to overshadow other less desirable qualities.

The similar-to-me-syndrome: Sometimes the human subIiminal vanity comes out in the interview. Hiring one who 
reminds one of themselves does not always ensure success for the job applicant.

The running mouth syndrome: In a one hour job interview, the interviewer should speak at most 15 minutes. Too many times interviewers run over this time limit. 8

The latest trend in interviewing is situational interviewing using structural situational questions. 9 Dr. Larry Harmon, a Coconut Grove psychologist, is one of the innovators of this more scientific process in finding the right person for the right job.

Dr. Harmon's interview process is based on the concept that by rating answers to previously answered questions by experts on the same question, interviewers can determine the potential success of an applicant by how closely their answers are to that of the experts.

\section{Checking References}

The next area of the personnel program involves the checking of past employment references of the job applicant. According to statistics compiled by the Department of Commerce, 30 percent of all business failures result from the dishonest acts of employees. Poor hiring practices, such as the failure to check employee references, are often the reason so many dishonest employees are hired. To simply employ a job applicant regardless of job position does not constitute reasonable care. It is not a sound business 
practice. ${ }^{10}$ Past employment patterns of a job applicant are usually indicative of a job applicant's potential. Hiring problem employees can result in expensive business losses, disrupt a smooth business operation and dampen employee morale. As part of the management concept of risk management safety and security, a preventative attitude must be implemented within hiring practices. probably one of the most cost effective methods of determining vital facts about an employee's potential can be achieved through reference checking. ${ }^{11}$ This method is one of the most inexpensive and simplest methods in screening out potentially dishonest job applicants.

Unfortunately, many employers shy away from screening employees because of the fear of potential litigation. This litigation usually involves job discrimination against minority job applicants. However, most employees do not know that federal law does not prohibit the checking of references of potential job applicants.

The Equal Employment Opportunity Commission (EEOC) is the branch of federal government that deals with employeremployee relationships. This commission adopted uniform guidelines in 1978 that outlined what an employer could ask a potential job applicant.

Additionally, a number of federal and state laws affect the manner about how an employer gathers information on prospective employees. For example, Title VII of the Civil 
Rights Act of 1964 bans discrimination because of race, color, religion, sex or national origin. However, this act applies only to employers of 15 or more employees.

To avoid problems involving discrimination, employers regardless of size, need to keep statistics on the number of male and female workers employed. Also, the selection system used to hire employees and how this system is job related is necessary.

The key to avoiding discrimination is to make certain that employment questions are job related. While questions such as physical requirements, availability and marital status may appear discriminatory they are not if the questions on these matters are job related. When reference checking, you must ask questions that relate solely to the particular job. ${ }^{12}$ knowing what questions to ask can be determined by reviewing specific job descriptions management has created.

Below are questions that may be asked on a typed reference check:

-Did this person work for you between the following dates?

-What was their salary at that time?

-What were their specific job duties?

-Did you work directly with this person? If not, who did?

-Why did the person leave your company? 
-Was this person friendly with co-workers?

-Would you hire this person again?

If a question comes to mind as a manager is checking references and you feel the question might be discriminatory, then don't ask it. However, as long as proof can be shown that questions being asked on a reference check are job related, the possibility of a job applicant bringing litigation against a potential employer will normally never occur.

Training

The next step of the personnel program is to develop a training program for each particular job area. This increases worker skills and knowledge about the job. "Not training employees, regardless of hotel size or job position can seriously inhibit their performance," says Dalton MCFarland, a personnel consultant. ${ }^{13}$

The training program can be broken down into three areas. Each can cut across the other or be modified depending on the particular management needs. These areas are orientation, job training and future development.

orientation. The purpose of an orientation program is to provide the new employee with the following information:

-To show the employee the organization, its goals and its structure.

-To define an employee's position within the company. 
-To tell the new employee what is expected from them.

-To let the employee know what they can expect from the company.

-To establish lines of communication between the employee and management.

This program can be done formally or informally, depending upon management's goals. It is important that the individual or group that has been designated for employee orientation have a thorough knowledge of the particular business. Possibly using handouts for the new employee greatly enhances their chances to learn quickly about the new company.

In short, a new employee should come away from the orientation program knowing the purpose, the structure and the expectation management has of that employee. 14

Job training. A method of training designed to provide practical, realistic experience under the supervision of management or a more experienced staff member. ${ }^{15}$ This is merely on-the-job guidance and instruction. Regardless of job position, the job training program is important for the employee.

The level of job training an employee will need depends on several variables. The most important variables are past experience and the willingness to learn a new system. Areas to be covered while the new employee is being trained include policies and procedures for a department, equipment 
usage, work techniques and the basic skills necessary to do a job safely and correctly.

Following these few guidelines will make the job easier for both management and staff.

Future development. This involves increasing the knowledge and ability of an employee's job position through additional skill acquisition and compensation. There are three basic approaches to increasing the future development of job skills in an employee. ${ }^{16}$ The first method involves internal development through the use of educational materials for that job position, seminars held by industry professionals and lectures given by upper management. This internal method is for the more self-disciplined employees who wish to advance within the company. An example would be a rooms maid learning a particular management style through relatedr? literature covering management so that she could become the rooms maid supervisor.

The next method is the external development. Here management gradually increases the workload of an individual employee. The emphasis of this training is to increase the individual's output of work given the normal number of work hours in a given day, should the employee increase their productivity, further advancement can be considered.

The last approach is a combination of the internal and external development for the employee's future. This method is used mostly with management persons who are seeking 
opportunities for advancement within an organization. This approach is increasingly time consuming, expensive and normally requires the cooperation of staff and management at a business operation.

\section{Employee Turnover}

Turnover is defined as the termination of employment for any reason. This includes transfers, termination for cause and employees who quit. Despite the high cost of turnover in the hotel industry little has been done to slow down this problem. Many studies have been undertaken to substantiate specific reasons why the hotel industry is besieged with high turnover. These studies indicate the major reasons to be low pay and poor supervision by management. 17

Another part of the problem involves hidden costs that are not quantified by most businesses, especially the hotel industry. For example, for every employee leaving the business, there are three basic costs involved. Separation costs involve the interviewer's time, administrative functions and separation pay. The next cost is replacement costs. These involve job advertising, administrative costs, interviewing and staff meetings. The last cost is the training costs. These include information literature, staff time and administrative functions. Should turnover occur Erequently in one or more specific job areas, costs of 
several thousand dollars can soon add up. 18

Regarding the employee's attitude to turnover has been addressed by noted human relations expert, Victor H. Vroom. In his book Work and Motivation, Mr. Vroom theorizes that employees ". . . are not motivated when they realize that there is a lack of opportunity to achieve what they expected when they were hired."

Certain fundamental information is needed when addressing the problem of employee turnover. This involves obtaining data for the following:

1. The number of terminations. This data can be placed into job position, salary, department or whatever management feels is necessary.

2. Reasons for termination. Several categories that can be covered in this area are money, relocation, better offer, dissatisfaction, layoff or termination for cause.

3. Length of service. This category includes areas such as employee morale, supervisory weaknesses and employee habits.

Statistics in these three categories will help delineate the particular reasons as to why turnover may be high.

\section{Conclusion}

The management of people is becoming more complex. With the everchanging economic conditions, legal restraints and especially changes in social values, personnel management 
techniques must also adapt to these complexities. Efficient personnel procedures must be developed and adhered to as part of the risk management safety and security program. People within the organization of a hotel will cost money. But those same people can also make money for the hotel if management is aware of their needs. 19

The careful selection, training and managing of the personnel in the business will lead to a more prosperous business.

\section{Lock and Key Control}

\section{Introduction}

The problem with key control has plagued the hotel industry since the beginning of the first inn. Simply put, there appears to be no foolproof key control system in existence today. As long as people are involved with keys there will be a problem.

stories abound among industry insiders and lodging guests having their rooms burglarized with no forced entry. Thieves have been caught carrying a suitcase full of various hotel room keys. 20 on a recent 60 Minutes special filmed in Las Vegas, viewers saw first hand, thieves selling room keys, master keys and other paraphanalia to gain illegal access to the hotel guest rooms.

The success of the key control system is therefore determined by preventative measures that a hotel utilizes. 
This "preventative" method, rather than an "after the fact" method, is an extremely important part of key control. Once a guest room key is given to the hotel guest little control over that key can be exercised. Probably one of the most innovative methods of key control ever created is the "Passport" key control system developed by Hyatt Hotels. On all their guest room keys is a numerical code that does not have the room number on it. This blind code must be matched with a correlating code at the front desk of the hotel. The code, room number and other pertinent information is recorded on the passport. Additionally the passport serves as guest identification for service employees. Guests who wish to charge various services to their rooms must present this passport before being allowed to do so. While this passport system is not foolproof it is a step in the right direction for key control.

Another innovative measure is the new computer locks that are being installed in hotel rooms. This type of key control system contains a microcomputer and a peripheral device that punches out various code patterns on a plastic card key. 21

This programmable "key" lock is a credit card size piece of plastic or paper that inserts into the lock that has the ability to change codes with each new guest. While critics of this system say that the locks can be easily manipulated, this computer lock does lessen the opportunity 
for criminals to gain illegal entry into the guest rooms. Unfortunately, because many hotel criminals include the hotel staff, such as maids, this system is only as good as the people working at the hotel.

The oldest method of key control used by the industry involves a re-keying effort for every hotel room. The standard rule as suggested by The American Hotel and Motel Association is to re-key every 18 to 24 months. Many hotels have the locks changed in a hotel room every time a burglary occurs in that room. While this will not stop fugure burglaries in a hotel room, it serves two purposes. First, it shows the hotel is using reasonable care in trying to provice safety and security for hotel guests. Secondly, it may pinpoint a situation of employee theft. At this point a determination can be made so as to who the employee-thief might be.

As part of the risk management safety and security concept, an understanding of the various types of locks available is needed. There are basically six types of lock and key systems available on the market today.

\section{Types of Lock Mechanisms}

\section{Warded Lock Mechanisms}

This type of lock uses fixed obstruction (wards that project from the inside of the cylinder lock housing. These wards block the entrance of the key and rotation of the key 
in the lock. Consequently, only the correct key or charge key will properly operate this lock. The idea behind the ward lock is to restrict the use of such manipulative tools such as lock picks.

Warded mechanisms are the oldest and simplest and above all least secure of all basic key operated locking systems in use. A simple bent piece of wire is all that is needed to open a warded lock.

\section{Tumbler Mechanisms}

The tumbler system is any lock mechanism having moveable and variable elements which depend on the proper key or keys to arrange the tumblers into a straight line. When this occurs, the lock can be opened.

The change key that operates this mechanism has a particular combintion of cuts and bitting which match arrangements of the tumblers inside the lock. This combination of tumblers can usually be changed periodically by removing the old tumbler arrangement and inserting a new tumbler arrangement and cutting a new key.

It should be noted that tumbler mechanisms and the keys that operate them are produced from specifications which differ from manufacturer to manufacturer. This is for security purposes.

The various arrangements of these tumblers permitted in a lock series are called the combinations. The number of 
combinations available within a specific lock depends on the number of tumblers used and the depth interval of each tumbler. For example, one tumbler with 10 depth settings provides 100 different combinations for key codes. The more tumblers used, the more key codes available.

\section{Disc or Wafer Tumbler Mechanisms}

This type of lock consists of three components. The key, the cylinder plug and the cylinder shell. The cylinder plug contains the springloaded tumblers which move up and down vertically. When the correct key is inserted into the cylinder plug, the tumblers come into a straight line so that none of the tumblers extend into the shell. Unfortunately, disc mechanisms generally provide only moderate security with limited key changes or combinations.

This type of lock can be easily manipulated with a pick by a person with minimal skill.

\section{Double-sided Keyway Mechanisms}

Two sided key and locks provide no more security than a single sided key and lock.

\section{Pin Tumbler Melchanisms}

This type of locking mechanism is the most common type of key operating locking mechanisms. This lock is used in the majority of builders hardware in the United States. The degree of security afforded by this type of lock ranges from 
poor to excellent. The major differences between the better locks and the cheaper models are determined by the number of tumblers and width tolerances found within the cylinder housing of the lock.

This particular lock is similar to the disc tumbler mechanism. The unit is composed of a key cylinder plug and a cylinder shell. Instead of the discs being used as the primary interior barrier, this type of locking mechanism uses pins. Each lock contains an equal number of upper and lower tumbler pins. When the correct key has the proper cuts to match the lower pins, the top pins become aligned with the top of the cylinder plug which unlocks the mechanism.

of particular importance to the hotel industry is the variations of the pin tumbler cylinders in the market. Currently the most popular model utilized is the removable core cylinder (Winfield lock). Using a special control key, the entire pin tumbler mechanism (the core) can be removed from the shell. This makes it possible to replace the cores easily without having to make up a new key.

Removable core cylinders do not provide more than adequate security. Most of these systems use a common control key that is similar to a master key. Duplicating this key is easily done. Another drawback to removable core cylinders is the added control pins inside the core increase the number of shear points. This translates into increased 
vulnerability to manipulation by thiefs.

\section{Types of Lock Bodies}

There are five basic lock bodies used in the United States today. 22 They are the rim-mounted unit, mortise, cylindrical and tubular. The overwhelming majority of businesses use the mortise and tubular types of locks in the United states. ${ }^{23}$ The mortise lock is the superior lock on the market and has been since its introduction in 1928.24

Because of their overwhelming popularity in the hotel industry this study will review only the mortise, cylindrical and tubular lock bodies.

\section{The Mortise Lock}

This solid lock body is installed by hollowing out a portion along the leading edge. The lock is inserted into this cavity. These mechanisms require a door that is thick enough to withstand this hollowing out. Usually they are placed in steel doors.

This lock is expensive to install initially but has a life expectancy of over 25 years.

Originally the mortise lock had the key cylinder mechanism held in place with a single screw. This proved to be ineffective against pulling the lock out of its cylinder with a pipe wrench. Today, cylinder guards make this lock virtually impossible to manipulate. ${ }^{25}$ For added security the mortise lock unit has a removable core cylinder so 
re-keying can take place in a matter of seconds.

The mortise lock provides the most safety and security for a hotel guest roomdoor. The unit contains both a latch bolt and a dead bolt with an auxiliary guard latch between those two bolts for added security.

The Cylindrical Lock

This unit is often referred to by people as the doorknob lock. This is because the cylinder lock unit is located within the door knob. In this type of lock the locking element is the latchbolt. This lock unit is vulnerable to most forms of manipulation. For example if the doorknob is knocked off the door, the lock is rendered useless. This unit is easily bypassed with the use of a credit card between the door trim and the door lock. The curvature of the latch bolt is designed for ease of entry and exit, not security.

This type of lock should be supplemented with a tubular deadbolt lock to provide aciequate secuidty.

The Tubular Lock

This lock unit is fast replacing the mortise lock unit The primary reason being that it is much easier to install and offers more than adequate security. It is fast becoming a primary lock for security purposes. Currently the trend in residential homes being constructed across the country today is to use this tubular locking unit in the doors of these homes. Application has also been introduced into the constuction of office buildings. Besides the ease of 
installation this lock offers adequate security against most forms of manipulation.

Strikes

The strike is the metal frame made of reinforced steel that the latch bolt or dead bolt fits into. This is usually an overlooked part of safety and security in the installation of lock units. Most strikes are installed with two or three screws of one or two inches in length. This makes prying off the strike much easier than if three and one half inch screws are used. Higher security strikes incorporate a reinforced lip to prevent possible jimmying and shimming of the lock unit. It should be noted that when installing a strike, the screws should be offset. This eliminates the possibility of splitting a wooden door frame or weakening a metal door frame by placing the screws in a straight line.

\section{Combination Locks}

Because of modern technology these locks are hard to manipulate. Sound baffling devices, nylon tumblers and improved lubricants have produced a lock that is by far one of the most secure in the industry today. Lock combinations are varied enough so that the coincidence of two locks having similar combinations is non-existent. To determine the quality of a lock, a tolerance check is needed. If the combination is 10-20-30, but the lock opens up on 9-22-31, this lock has wide tolerances. This adds up to less than 
adequate security. The biggest problem with combination locks is trying to keep the particular numerical combination safe. Stories abound of employees leaving the code written on a piece of paper in plain site. Many people preset the first two codes on a combination lock. All an interested third party would have to do is figure out the third number to a combination and the lock is open.

\section{Establishing a Key Control system}

To properly implement a successful key control system, several preliminary steps must be taken. The following is a suggested format necessary to implement a successful key control system within hotel operations.

The first step involves a survey of the hotel property to determine the types of locks being used. Next, we analyze the problems with the current key control system, if there is one, and an inventory of all existing keys currently available on the property. This is followed with a list of who possesses which keys to which areas of the hotel property. Determining who has which keys to the various hotel areas shows that reasonable care is being used by the hotel. The next step is to begin a filing system of all employees with a 1 ist of every key they need and where they will be used. Signatures, dates, key numbers and specific key use should be noted on the filing system.

Thirdly, a key storage facility that is protected by 
Iimiting access to the keys, dispersing key storage to various areas so as to limit the potential for loss, and lastly, not allowing duplication without management approval.

The fourth step involves periodic key reviews, key audits and unnounced key inventories. This is a "check-up" for the key control system. A check-in and check-out system for all hotel property keys is one method of minimizing the opportunity for losing keys.

Lastly, key control records must be kept up to date and constantly checked for verification. The lack of daily records and efficient record keeping due to sloppy clerical work is the single most dominant reason for the breakdown of a key control system.

Critiquing the Traditional key Control system

The most widely used key control system in the United states today is the master keying key control system. 26 The system is divided into various sections. The grand master key, as the name implies, would normally open any lock within a building structure. A sub-master key would only open a specific section of the building. An operating or change key would open only an individual lock.

The biggest weakness to this system is that a master key system makes lock picking easier. This is because multisegmented pins inside the tumbler mechanisms need to raise a shorter distance to operate the lock. This means 
the more keys that open an individual lock reduces that lock's effectiveness as a security barrier.

One method to reduce this lock picking is to buy UL approved pick resistant locks. These various styles of locks use a more break resistant hardware.

The reasor: that the master keying system is so widely used by management is because of convenience. It allows easy access to any lock in a building with only one key. However, if this key is lost or duplicated by the wrong person, every lock within that building structure is now insecure. While a master key system has an initially higher cost to begin with, the operational cost is lower. If this master key system is to be used by a hotel property, then not using the grand master key would be highly advisable. Master keying at different levels is a solution that many hotels have chosen. Some have even chosen to use nonstock type keys that must be duplicated by factory machinery. These keys can only be duplicated at their place of purchase. Most standard key designs can be duplicated by any locksmith or thief with minimal skill.

"The real secret to maintaining key control is really very simple," says Michael Pascal, a security consultant, "do not issue any keys." 27 While this is a solution to the key control dilemma, it is unrealistic, especially in the hotel industry. 
Conclusion

The overall effectiveness of a lock and key control system is determined by the degree of care utilized in the planning of the system. For example, the door frame is as important as the door and the locks being used. In other words a chain is only as strong as its weakest link. Using the most expensive locks on the market is useless if adequate key control systems are not properly enforced.

The use of illicit keys to gain entry into a hotel room by criminals is one of the most common methods used by the individuals. Each year thousands of keys are lost and stolen from hotel rooms. Many of these keys fall into the wrong hands. Leaving keys on maids carts, room numbers on keys, leaving keys in locks accidently and losing keys in general are practices that must be educated against repeatedly in the hospitality industry.

The sole purpose of any good lock and key system is to prevent illegal access into a property. However given the right tools, enough time and a careless employee any lock and key control system will quickly be rendered useless. The main goal of any lock is to make illegal entry by force as difficult as possible. While forceful attacks on locks are not the norm, they often occur and should be prepared for. Since most theives pick the simplest and easiest targets on which to commit a crime, these forceful attacks, as previously mentioned donot occur often. But they do actually 
happen often enough that not providing an adequate locking unit in a hotel guest room is a lack of reasonable care.

\section{Lighting}

Introduction

There is a close relationship between lighting and crime. A recent study by the National Crime Prevention unit determined that lighting can be part of an effective program against crime. The criminal element has traditionally chosen the easiest target in a burglary attempt. Through the proper application of interior and exterior lighting in sensitive areas, such as parking lots, alleyways and hotel grounds, can be made safer and secure.

To gain an insight into the importance of lighting in risk management safety and security a fundamental understanding is necessary of the concept of lighting.

Lighting has been providing protection for mankind since the discovery of fire. ${ }^{28}$ The tribal fires of early man in its stationary form provided safety and security from nature's element. This artificial light was an excellent tool at turning night into day. No doubt the first person to pick up a burning piece of wood was the originator of the torch.

This idea of using fire to light up the night soon gave birth to fire baskets. The baskets contained burning embers elevated upon a tall pole. As late as the $1850^{\prime} \mathrm{s}$, parts of 
Russia and India still used these fire baskets to illuminate large areas of the communities. 29

In 1662, an Italian named Lardati obtained a license from the French goverment in Paris to begin a night escort service. Setting up booths in the paris streets, lanterns could be rented by pedestrians to walk through the dark streets at night to get from one section of town to another. 30

Medieval Europe was forced to begin this practice of night illumination due to the ever increasing numbers of street crimes being committed on pedestrians walking the streets at night. Local city homeowners were asked by the various town goverments to hang lanterns outside their homes from sunset to sunrise. Because this was not a mandatory law, few residents complied with the order.

In 1720, the kings court of Common council meeting in London decreed an official order forcing homeowners with homes fronting public streets in downtown London to hang lanterns outside their homes at dusk until midnight. This was the first time that a goverment had intervened with mandatory legislation to regulate lighting to promote the safety and security to the general public.

Goverment provided public lighting first occurred in downtown Cleveland, England in 1877 using electric arc lamps and thus established the first public lighting syster. in the world. This marked the beginning of night illumination on public streets. 
in understanding how lighting affects our daily lives. This is especially important in business but extremely important to the hotel manager. Below is an outline of several types of lighting sources that are currently on the market available to the public.

\section{Incandescent Lighting}

This light source is the most widely used in the world today because of its simplicity. Electricity is sent through the light bult into a coiled tungsten filament in a vacuum until it glows. The advantages of this type of light source include low installation cost, unaffected by ambiant temperatures and excellent color rendition. The disadvantages include tremendous energy-waste and high operating cost. About 90 percent of the energy used by the incandescent light is dissipated as heat not light. An important rule of thumb when using this type of light is to remember that efficiency does increase as wattage increases.

\section{Fluorescent Lighting}

This light source uses electricity to excite gaseous atoms within the fluorescent tube to produce light. The electrical charge is sparked in the ballast and flows through cathodes at either end of the tube. This light source provides good color rendition, has a long life and wastes little energy. The only drawback is that they do not emit light over long distances. Additional fluorescent 
lamps without a silicone coating over the lamp are affected by humidity. Higher starting voltages are needed for the lamp. This increases the use of energy and reduces the life of the light. This lamp works best in an ambient air temperature of around $78^{\circ}$.

Outdoor Lighting

Outdoor lighting requires the use of high intensity discharge lamps. This is due to long periods of time these light sources will be operating. The three most efficient light sources available on the market today are the mercury vapor lamp, metal halide lamp and low pressure sodium lamps. Seventy-five percent of the street lamps in the United States are of the mercury vapor type of light source. These lights have extensive operating life cycles of over 24,000 hours (almost a seven-year life span) and provide excellent color rendition.

Metal halide lamps have a life cycle of up to 6,000 hours and are used primarily for their excellent color rendition.

High pressure sodium lamps were first introduced in 1965. This light source is still used extensively today. Their life cycle is around 24,000 hours. The strongest advantage of this lamp is that it retains up to 90 percent of its lighting capacity throughout its life.

Police department officials across the nation uniformly 
agree that high pressure sodium vapor lights provide the best security lighting of all outdoor lighting available. ${ }^{32}$ It should be noted that the shape of all outdoor lamps is important. The design provides an optimum internal environment for maximum tube performance in the lamp bulb. Additionally, they provide light direction distribution patterns because of their shape. This is especially important to hotel managers wanting to illuminate especially dark areas of a hotel property.

Developing an Effective Lighting Program

Effective lighting of a hotel property is an essential element to risk management safety and security. While using the correct type of lighting is most cost efficient, the bottom line is simply to illuminate the property at night to prevent potential problems from occurring. This night illumination when done properly is one method of providing hotel guests with safety and security. It is without question a definite psychological deterrent against crime. The first step of the hotel lighting program is to separate the property into three zones. Zone 1 will include exterior parking lots, alleyways and walkways. Zone 2 will include walls and entrances around the hotel. zone 3 will include the interior lighting of guest rooms, offices and other rooms located within the hotel property.

Each zone will require different standards of 
illumination. These standards are set by the various city and county government codes. The usual term to describe lighting efficiency is in footcandles. This is defined as the illumination on a surface one square foot in area on which is uniformly distributed one lumen of light. 33 lumen is the output of a light source)

Suggested levels of illumination for the three zones are: Zone 1 varies from 0.02 to 1.0 footcandles. Zone 2 varies from 0.5 to 2.0 footcandles. Zone 3 varies from 1.5 to $3.0+$ footcandles. ${ }^{34}$ These intensities will vary depending on several variables such as area crime statistics, purpose of interior rooms, city and county government regulations and neighbors' complaints.

In terms of the "reasonable care" attitude it is better to over illuminate a hotel property than under illuminate. The next step involves identifying the critical areas around the hotel property where guest safety and security may be jeopardized. Examples of this would be the rear alleyways behind the hotel property, guest rooms at the side and rear of the building, ice and concession machines and swimming pool area. Several multimillion dollar lawsuits have come about due to inadequate lighting of these particular areas.

Savings may be noticed by reducing or eliminating lighting from semi-active hotel entrances. However, this is 
a lack of reasonable care. There is no doubt that many entrances and exits, such as fire exits, are seldom used by the hotel guest. However, it is foreseeable that these entrances and exits would be used by some patrons. It would be unwise to eliminate lighting from any entrance or exit at night because of a lack of usage.

other critical areas include utility closets, hotel equipment closets, supply closets and other similar areas that could be vandalized or attacked should be well illuminated.

The next step would be to periodically inspect the lighting units around the hotel property. Documentation of this inspection is important. Reviewing for burned out bulbs, decay of electrical wiring, luminaire surface depreciation and manipulation should be noted. A record of this inspection certainly meets the requirement of reasonable care in making certain the property is correctly illuminated as well as safe.

It should be noted that a dust laden lighting unit can have losses as much as 50 percent of its illuminating capacity. While ventilated fixtures allow the lighting unit to operate at a cooler temperature they also become dirtier sooner. An enclosed lighting fixture may cost more initially. The benefits, however, include a cleaner and brighter light bulb and less susceptability to manipulation. 


\section{E. Fire Prevention}

Introduction

Fire has been a friend as well as a foe of civilization since its first discovery by man. Ehile fire has provided protection from his enemies and nature, warmth and light, man also realized that fire could be a deadly enemy if not properly controlled. Fire has destroyed his life, home and possessions. It is capable of destroying cities as witnessed by our history books. Rome, Chicago, San Francisco, were all virtually wiped of the maps due to uncontrolled fires on the rampage.

In the early development of the United states fire guards were appointed by the town councils to patrol the towns and warn of fire. Every homeowner was required to possess his own fire bucket, laddex and poles that could reach burning rooftops. These fire guards eventually became goverment employees called fire masters. Today we commonly refer to them as fire marshals.

Interestingly enough the first colony to be built in america, in Virginia, was destroyed by fire. ${ }^{35}$ The colony at Plymouth Rock suffered near destruction in 1623 due to fire. The reason fire was such a great threat to the early settlers. was because of the materials used in the construction of the buildings. With houses being so close together and the fact fire was used every day for cooking, it was only inevitable that total destruction of a town was going to occur.

It wasn't until the $1700^{\prime} \mathrm{s}$, when Benjamin Franklin 
recommended the formation of a volunteer fire company. However, nothing was done by the goverment until after the Great Chicago Fire in 1871. This renewed interest in the formation of fire fighting brigades by the goverment was a positive action step.

With the adoption of National Fire Prevention Week beginning in 1922, a national observance had begun. This day was to remind the country of the danger of fire.

Today in spite of modern fire fighting equipment, strict fire codes and hi-tech fire prevention systems, the problem with fire still exists.

A recent fire at a major downtown Atlanta hotel resulted in 400 rooms being damaged by smoke and fire in 1983. Fortunately no injuries resulted, but the threat of serious liability can result because of fire.

All lodging properties operate with an exposure to a degree of fire hazards. The key to minimizing those fire hazards is to implement as many fire prevention principles as possible within the hotel operation. While fire and similar emergencies may not be the primary responsibility of a department head in a hotel, it is important that all hotel managementbe aware of risk prevention safety and security principles.

Being prepared in the event of an emergency is a wise business practice. Furthermore in the event of litigation against a hotel due to a fire or similar emergency 
management preparation for these problems constitutes the responsibility of reasonable care that the lodging establishments owe their guests.

To offer incentives to lodging properties to utilize fire safety equipment in their rooms, tax advantages from the government have been introduced. ${ }^{36}$ senator Howard Cannon's (D-Nevada) bill S.878 provides tax incentives for the installation of fire protection devices in restaurants, hotels and night clubs.

While governmental incentives are beneficial to the hotel industry there is no substitute for effective fire prevention methods.

Fire is a chemical reaction that requires fuel, oxygen and heat to start and continue. Deprive one of these elements and there can be no fire. The actual causes of fire can be narrowed down to one element, people. The fire may have been started by faulty equipment, poor construction methods, poor inspection methods or just plain ignorance, but somewhere in the problem, human intervention was introduced. 37

\section{Types of Fires}

There are currently four classes of fires. Class "A" fires consist of materials such as wood, paper and fabrics. Water based extinguishants are used on this type of fire. class "B" fires involve flammable liquids such as grease, 
oil and paint. Using dry chemicals, foam type or water fogging type extinguishants will fight this type of fire. Class "C" fires include electrical appliances such as fuse boxes and electric motors. Dry chemicals and carbon dioxide extinguishants fight this type of fire. Class "D" fires consist of flammable metals and must be fought with special powdered chemicals. 38 This type of fire is the hardest to extinguish and usually results in severe property damage. A working knowledge of fire "classes" and extinguishing them is a wise management practice in risk management safety and security within the hotel.

In dealing with fires there is one simple rule that must be followed religiously, and that rule is "At the first sign of a fire, immediately call the fire department." 39

Developing an Effective Fire Prevention Program

An effective fire prevention program by hotel management is a wise business practice as well as cost effective in the long term results from which the hotel will benefit. While this program appears intangible at first, the effect a fire can have on a hotel property is staggering in terms of lost business and public opinion.

The first area of concern in developing this fire prevention program is the property inspection. A thorough review of the entire hotel property by management is most essential. The inspection format will vary from hotel to 
hotel. A systematic approach to inspection is well advised. This allows management to quickly review the major hotel departments to discover any problems.

The following Fire Prevention Survey was prepared by the Boston Fire Prevention Division and should cover the following areas: 40

1. Fire Vulnerabilities

2. Fire Alarm system

3. Emergency Lighting

4. Sprinkler system

5. Standpipe and Hose System

6. Fire Extinguishers

7. Exits

8. Finishes on Walls, Floors and Ceilings

9. Storage Closets

10. Utilities Shut-off Location

11. Laundry

12. Maintenance

13. Other

The inspection must be dated and include hazards found with their locations and recommendations for correction. A follow-up survey must be completed to document when the correction of a hazard has been completed.

Care must be taken during the inspection not to develop tunnelvision. This problem occurs when management begins to concentrate on specific fire hazards rather than general 
hazards. An example would be, concerning the survey with only the storage of flammable liquids while forgetting to check if a smoke alarm detector is functioning properly. Smoke Detectors

Up until the 1970's hotels relied on the manual fire alarm systems in lodging properties to warn guests of a fire within that property. These alarms are manully pulled after the fire has started and hopefully is discovered. Many times these alarms were pulled to late.

Because fire can travel at a tremendous rate given the right circumstances, many hotel guests have little time to escape. Manual alarms work on the assumption that someone will be around to spot the fire, but what if there isn't?

Based on the premise that where there is smoke there is fire, smoke detectors are the hotel industry trend today. These detectors have been on the market since the 1950's. Unfortunately, their cost has been a factor in not using them in hotel rooms.

There are currently several models of smoke detectors to choose from. All models work of two principles. The first uses air ionization principles to detect smoke. The second relies upon a photo electric beam to "see" smoke. The ionization smoke detector is the superior product of the two types. This detector works on a very simple principle. An air chamber inside the smoke detector contains ionized air. The air becomes ionized because there are 
radioactive particles bombarding the chamber within the unit. When smoke is in the air it seeps into this air chamber upsetting the ionized air, thus triggering the alarm. These devices are extremely sensitive and expensive. The drawback to the ionization system is that this system cannot detect plastic and paper fires due to this type of fire's lack of combustible materials.

The photoelectric system uses a beam of light as its sensing unit. If smoke passes into the light between this sensing unit, the light is dimmed, thus setting off the fire alarm. These systems are not as sensitive as the ionization smoke alarms. However, they also do not cost as much.

Drawbacks to these photoelectric smoke alarms include heavy dust particles, excessive cigarette smoking in the room and pranksters placing objects between the sensing units causing them to malfunction.

\section{Fire and the Media}

Public relations is an extremely important segment of the hotel industry. The handing of all media groups is a difficult task. This can be compounded during emergency situations, such as the outbreak of a fire within the hotel property. There are several ground rules that must be understood when handing the media during an emergency situation and for any public relations affair. 41

The first ground rule of public relations with the 
media is to have one and only one spokesperson. More than one spokesperson will almost always lead to conflict and confusion in an emergency situation.

The second ground rule is to obtain only the facts of an emergency situation. Obtaining correct information may be difficult, especially with an insisting media. Regardless of the media pressure to "let us know something," most industry experts agree that it is a wise business practice to say, "I'm sorry, but we don't know yet. When we do we will tell you." 42

The chances of a hotel manager having to explain a fire disaster to the public is slim. As part of the risk management safety and security program being prepared for fires and other emergency situations is essential for the smooth operation of a hotel property.

The last ground rule of this public relations segment is to keep a $\log$ of information released to the press and other media types. This aids in two ways. Firstly, it helps avoid duplication of already released statements about an emergency.

Secondly, the log can be used in case of any litigation arising from an emergency situation. Documentation helps refresh the menory and corrects any false information circulating about the situation. ${ }^{43}$ 
Conclusion

Despite the hospitality industy's agressive efforts to promote within the industy fire prevention and fire detection practices this practice is not a major management philosophy. Despite the tremendous losses annually from fire and smoke damage to modern man and his business enterprises, the everpresent threat of fire is still not shown the respect that it truly deserves.

Present fire code regulations are based on fire losses after the fact, rather than before the fact. This is ironic when one considers that the majority of hotel fires occurring in many hotels, occur in legally "safe" hotels which have passed their various state and local fire codes. 44 In spite of this fact, lawsuits for wrongful death litigation involving the hospitality industry, disregard this fact that the hotel may have been operating within various state fire codes. The jury, blaming the hotel, for a lack of "reasonable care", in a wrongful death suit, for example, will hold the hotel liable regardless. Why, you may ask? Simply, when it comes to the loss of a life or pain and suffering as a direct result of someone's negligence, then fault will be placed on the responsible parties at the time, the hospitality industry in this case, has that responsibility. 45 
SECTION III

Footnotes

$1_{\text {Robert Long, Property and Liability Insurance }}$ Handbook, p. 1096.

${ }^{2}$ Understanding Crime Prevention by The National Crime Prevention Institute, 1980, p.

${ }^{3}$ Garzilli vs. Howard Johnson Motor Lodge, $419 \mathrm{~F}$. Supplement 1210, 1976.

${ }^{4}$ William L. Siegal, People Management for Small Businesses, p.

${ }^{5}$ Dalton McFarland, Personnel Management: Theory and Practice, p. 280.

${ }^{6}$ Ibid, pp. $281-283$

${ }^{7}$ Linda Roxe, Personal Management for the smallex Company, pp. 34-35.

${ }^{8}$ Bruce Jones, Florida Trend, p. 100.

${ }^{9}$ Ibid, p. 99.

${ }^{10}$ U.S. and World News Report, $p$.

${ }^{11}$ Security Management, March, 1983, p. 11.

12 Ibid, p. 14.

${ }^{13}$ Dalton McFarland, Personnel Management: Theory and Practice, p. 291.

14 William L. Siegal, People Management for Small Businesses, p. 46 . 
${ }^{15}$ Linda Roxe, Personnel Management for the Smaller Company, p. 171.

16 Ibid, p. 172 .

17 Stanley Davis, The Cornell HRA Quarterly, May, 1983, p. 15 .

${ }^{18}$ Dr. Larry Harmon, Turnover Worksheet, July, 1984.

19 Edward Feeney, Training and Development Journal, "12 Ideas Toward Effective Training," September, 1980, p. 15. p. 1A.

${ }^{20}$ Laura Karesh, Orlando Sentinal Star, September, 1981,

${ }^{21}$ Marvin Grosswirth, "Theft-proof Lock Developed to Safeguard Hotel Rooms", Science Digest, October, 1979, p. 46 .

22 Lawrence J. Fennelly, The Handbook of Loss prevention and Crime Prevention, p. 153.

${ }^{23}$ Yale Locks Guide, 1984.

${ }^{24}$ Ibid.

${ }^{25}$ Robert L. Robinson, How to Burglerproof Your Home, p. 11 .

26 "Stopping Theft Dead in Its Tracks," Lodging Magazine, pp. 38-39.

27 peter s. Hopf, Handbook of Building Security Planning and Design (New York: McGraw Hill Publishing Co., 1979), p. 97 .

${ }^{28} \mathrm{~F}$. W. Robins, The story of the Lamp, p. 3.

29 Ibid, p. 4.

30 Ibid, p. 141. 
${ }^{31}$ Motel and Hotel Inn Journal, p. 17.

${ }^{32}$ Lawrence J. Fennelly, Handbook of Loss Prevention and Crime Prevention, p. 10 .

${ }^{33}$ Ibid, p. 97.

${ }^{34}$ peter s. Hopf, Handbook of Building Security planning and Design, p. 14. p. 5 .

35 William K. Bare, The Fundamentals of Fire Protection,

36 American Hotel and Motel Magazine, p. 15.

37 William Bare, The Fundamentals of Fire Prevention, p.

${ }^{38}$ Lawrence J. Fennelly, Handbook of Loss Prevention and Crime Prevention, p. 432 .

${ }^{39}$ Ibid, p. 433.

40 Assets protection by Boston Fire Prevention Unit, Vol. 4, No. 3, July, August, 1979.

${ }^{41}$ Richard $w$. Darron, The Dartnell Puablic Relations Handbook, p. 583.

42 Ibid, p. 584 .

${ }^{43}$ Ibid, p. 586

44 Fire Engineering, p. 173. The various owners of the MGM Grand Hotel in Las vegas stated that the hotel was well within compliance with existing fire codes at the time of construction. Proof was given by the fact that major portions of the hotel complex were sprinklered and had fire alarms. Eighty-four people died in this fire on November $21,1980$. 
45 Businessweek, p. 70. Despite alleged compliance with state fire codes, the MGM Grand Hotel is seeking over 170 million dollars in retroactive liability insurance. At the time of the fire, the hotel had only 30 million dollars of liability insurance. 
SECTION IV

\section{GENERAL PROCEDURES}




\section{SECTION IV. GENERAL PROCEDURES}

\section{General Overview}

This study concentrated on the five major problem areas found traditionally in hotel operations. They are general hotel safety and security personnel, key and lock control, lighting and fire prevention. These problems were addressed through the development of a risk prevention safety and security program. Based on a review of the material covering these problem areas, criteria were developed to determine the best methods available for handling these problems. A questionnaire was subsequently developed from this material, in an effort to determine how well local hotel operations are handiing these major problem areas.

\section{The Research Methodology}

This study utilized two types of research methodologies. The first was the historical methodology. This addressed the first subproblem through an analysis of the internal and external events in a somewhat chronological order, making up the history of hotel safety and security. This method allows for a systematic collection of pertinent information through the objective interpretation of historical events. As Walter Borg states,". - part of the solution to a problem is the understanding of that problem." 1 This 
researcher feels that an understanding of the historical dynamics of these major problem areas will lead to a more reliable data collection.

The second methodology involved is using the descriptive survey. This method requires the use of observation on a clearly defined population group. The most common observation instrument utilized by researchers involves the questionnaire. The questionnaire developed for this thesis consisted of 29 well defined questions. Through the critiques of professionals within the industry and material obtained from related literature, this questionnaire was determined to be accurate and non-biased. This questionnaire was further determined to be accurate from the preliminary responses from the tested population in the survey.

The researcher felt it was unfeasible to survey all the hotels in Miami. By randomly selecting 20 hotels throughout the Miami area an adequate perspective would be gathered.

\section{The Treatment of the Data}

The primary data for the historical research methodology of the risk prevention safety and security manual was obtained from related texts, published studies, magazine articles and various interviews with industry professionals.

Answers to the questionnaire by the selected population group were compiled and then presented in Part $V$ for analysis 
SECTION IV

Footnotes

${ }^{1}$ Walter Borg, Educational Research, p. 964. 
SECIION V

THE RESULTS 
SECTION V. THE RESULTS

\section{The Completed Survey Returns}

The risk prevention program survey was administered to randomiy selected hotels in the Miami area between July 10 and July 24. The sample members surveyed were all management individuals with several years of experience in the hospitality industry. The 29 question survey was analyzed and consequently used to accept or reject the hypotheses.

Hypothesis I

This hypothesis was supported and accepted. Tables I through $V$ conclusively prove that the majority of hotels surveyed have adequate risk prevention safety and security pplicies and procedures in writing. However, when it comes to addressing these policies and practices within the major areas of hotel operations they are not always practiced.

Table I reviewed the overall hotel safety and security of the hotel operation. The first area covered in this section involved the hotel's perimeter characteristics. All survey members, 100 percent, regularly toured the property, provided guests with important hotel information, and had a liaison developed with local medical, fire and police officials. However, these are all standard practices in the hospitality industry. The next area of hotel perimeter 
characteristics reviews access control of the hotel property. This area asked more direct questions about specific risk prevention safety and security practices. Of the 20 hotels surveyed, 90 percent had door frames made of a solid type material, while 10 percent did not. The solid material included steel door frames and solid core doors made of wood or steel.

Having the guest rooms checked for vulnerable areas such as faulty door locking mechanisms found 80 percent of the hotels practicing risk prevention in this area, while 20 percent did not. The response most commonly given for not checking for vulnerable areas was to wait until a guest complaint was registered.

Marking full length windows and doors with decals to protect against being accidently being walked into found 85 percent of the hotels marking the windows, while 15 percent did not.

The last area of access control reviewed documentation showing that the necessary steps had been implemented within the hotel operation to diminish access control problems. Only 70 percent of the hotels surveyed followed this practice, while 30 percent did not document access control problems.

The last area of hotel safety and security reviewed the hotel employee's awareness about these matters. Employees looking for unsafe conditions while working on the hotel 
property found 85 percent of the staff performing this practice, while 15 percent stated they did not have employees look for unsafe conditions.

Keeping storage and supply rooms organized found 85 percent of the hotels practicing this, while 15 percent did not. The practice of having employees use their carts to block the entrance to a hotel guest's room while being cleaned was also practiced by only 85 percent of the hotels, while 15 percent did not practice this safety and security method. The most serious safety and security problem involved leaving valuables on maids' carts, most notably room keys. Seventy percent of the hotels surveyed had valuables of one kind or another out on the maids' carts.

Table II reviewed the particular personnel policies and practices at the various hotels. Screening employees was practiced by only 85 percent of the hotels, while 15 percent of those surveyed did not screen the people hired. Strangely enough, only 50 percent of those hotels that screened employees bothered to record the responses to the screening. The other 50 percent did not make documentation of the screening available. Most hotel employees, 85 percent, received some type of formal or informal training about their particular job duties. Strangely enough, 15 percent of the hotels surveyed did not offer some type of training for employees. 
The lowest statistic of the entire survey was the question involving job descriptions. Only 45 percent of the hotels provide the employee with a list of particular job responsibilities, while 55 percent provide no written insight about how to do a job.

Table III reviewed the key and lock control systems used by the surveyed hotels. All the hotels in the survey, 100 percent, had a key control system of some type. The most popular key control system was the master key system, while the most popular lock system was the replaceable key cylinder units. Using mortise dead bolt door locks was found in only 70 percent of the hotels. The other 30 percent opted for the less secure and cheaper key-in-the-knob door lock. Using auxiliary door locks of one type or another was practiced by 85 percent of the hotels, while 15 percent felt that this was not necessary. The trend towards placing $180^{\circ}$ peephole viewers was found in 75 percent of the hotels surveyed, while 25 percent did not use them. The trend here appears to be using these viewers in hotels with indoor corridors. The re-keying of door locks can be broken down into two distinct categories. First are the hotels that have re-keyed within the last six months. According to this survey over half the hotels had re-keyed within that time frame. The second and more realistic category is hotels that re-key "as needed." This trend appears to be more prevalent in the industry. 
Table IV reviewed the lighting policies and procedures at the hotels in the survey. According to the results, all, 100 percent, hotels had the hotel property adequately illuminated at night. The responsibility to report burned out bulbs primarily is the responsibility of the entire hotel staff according to the survey results.

Table $V$ reviewed the various hotels in the survey for fire prevention practices. This section of the risk prevention safety and security program produced the most alarming results. Only 70 percent of the hotels in the survey had an emergency plan of action in writing for employees about what to do in the event of a fire. Over 30 percent of the hotels had nothing more than instructing an employee verbally to call the fire department. Having all standpipes, fire extinguishers and fire prevention equipment checked regularly found all, 100 percent, of the hotels complying with this policy. This is because these items are regulated by local and state governments. The most alarming statistic of all was that only 80 percent of the hotels had developed a plan to contact the guest in the event of an emergency. Twenty percent had done nothing. The most common answer here was that if they smell smoke they will hopefuliy leave the room. Another 100 percent answer in this section was the question regarding combustible materials and their storage. The trend here appears not to use any products that are flammable or explosive unless it 
is a necessary part of the hotel operation. The second most alarming fact in this section appears to be the lack of training of the hotel staff and management in the event of a fire or other emergency situation. Only 60 percent of the survey members received a training program in the event of an emergency, 40 percent of those surveyed received no training. Fortunately, the trend in using smoke detectors and sprinkler systems throughout hotel properties was found in 95 percent of the hotels surveyed. OnIy five percent of those surveyed did not utilize some type of fire prevention equipment. 


\section{TABLE I}

\section{THE HOTEL SAFETY AND SECURITY SECTION}

\section{A. PERIMETER CHARACTERISTICS}

1. Is the property toured on a regular basis by management and staff to look for unsafe conditions in the exterior and interior of the hotel?

Yes $100 \%$

No

2. Are all hotel guest rooms provided with appropriate literature regarding innkeeper's law, fire exit maps and other pertinent information?

$$
\text { Yes } 100 \%
$$

No

3. Is the proper signage for exits, pool areas and other vulnerable areas utilized?

$$
\text { Yes } 100 \% \text { No }
$$

4. Has a liaison been developed with local medical, fire and police officials for emergency and non-emergency situations?

$$
\text { Yes } 100 \%
$$

No

B. ACCESS CONTROL

1. Are all door frames and doors made of a solid material?

$$
\text { Yes } 90 \% \text { No } 10 \%
$$

2. Have guest rooms been reviewed for possible vulnerable areas, such as faulty door and window locking mechanisms in the last month?

$$
\text { Yes } 80 \% \text { No } 20 \%
$$


TABLE I (continued)

3. Have all windows of full length or more been marked or protected against being walked into?

$$
\text { Yes } 85 \% \text { No } 15 \%
$$

4. Is documentation available showing the steps taken to diminish the problems associated with access control?

Yes $70 \%$ No $30 \%$

C. EMPLOYEE AWARENESS

1. Do employees look for potentially unsafe conditions while performing their particular job duties?

$$
\text { Yes } 85 \% \text { No } 15 \%
$$

2. Are storage and supply rooms kept neat and orderly?

$$
\text { Yes } 85 \text { 웅 No } 15 \%
$$

3. Are employees taught to use their carts not to block guest room doors while cleaning?

Yes $85 \%$ No $15 \%$

4. Are valuables of any kind found on the maids carts?

Yes $70 \%$ No $30 \%$


TABLE II

II. PERSONNEL

1. Are all hotel employees screened prior to working for the hotel?

$$
\text { Yes } 85 \% \text { No } 15 \%
$$

2. Is this screening process documented?

$$
\text { Yes } 50 \% \text { No } 50 \%
$$

3. Do all hotel employees including managers receive some type of formal or informal training for their job duties?

$$
\text { Yes } 85 \% \text { No } 15 \%
$$

4. Does the hotel provide job descriptions for all employees working on the property?

$$
\text { Yes } 45 \% \text { No } 55 \%
$$


TABLE III

III. KEY AND LOCK CONTROL,

1. Does the hotel have a functional key control program currently operating within the hotel?

$$
\text { Yes } 100 \% \quad \text { No }
$$

2. Does the hotel use mortise deadbolt locks that are U.L. approved in guest rooms and other vulnerable areas?

$$
\text { Yes } 70 \% \quad \text { No } 30 \%
$$

3. Are auxiliary locks used inside the guest rooms?

$$
\text { Yes } 85 \% \text { No } 15 \%
$$

4. Are all guest room doors equipped with $180^{\circ}$ peephole viewers?

$$
\text { Yes } 75 \% \text { No } 25 \%
$$

5. Guest room door locks were last rekeyed month (s) ago. 
TABLE IV

IV. LIGHTING

1. Is there adequate lighting on the hotel property for all vulnerable areas such as entrances and exits?

$$
\text { Yes } 100 \% \text { No }
$$

2. Has the responsibility for replacing light bulbs and fixtures been assigned?

Yes $100 \%$

No 
TABLE V

V. FIRE PREVENTION

1. Does the hotel have a plan of action in writing on what to do in the event of a fire or other emergency?

Yes $70 \%$ No $30 \%$

2. Are all standpipes, fire extinguishers and other fire prevention equipment checked regularly?

$$
\text { Yes } 100 \%
$$

No

3. Has a method of contacting hotel guests been established in the event of a fire?

$$
\text { Yes } 80 \% \text { No } 20 \%
$$

4. Are combustible materials stored in a safe place and disposed of properly?

$$
\text { Yes } 100 \% \quad \text { No }
$$

5. Has the hotel staff and management been trained what to do in the event of fire and other emergency situations?

$$
\text { Yes } 60 \% \text { No } \underline{40 \%}
$$

6. What type of fire pevention equipment, furnishings and other similar materials does the hotel utilize to prevent possible fire hazards? (Example, smoke detectors and sprinkler system in guest rooms)

$95 \%$ had 
Hypothesis II

Due to the time constraints and lack of funding for this type of project, the second hypothesis was neither approved nor disapproved. Whether or not this study to develop a risk prevention safety and security program can diminish the major problem areas of hotel opeations is a matter of speculation for now. 
SECTION VI

SUMMARY, CONCLUSIONS AND RECOMMENDATIONS 
SECTION VI. SUMMARY, CONCLUSIONS AND RECOMMENDATIONS

Summary

The threat of litigation against a hotel property is on an ever increasing cycle. Today the public is looking for every opportunity to place liability on someone or something else. This liability is usually in the form of negligence. Negligence allows the courts to award those who have been wronged compensatory and punitive damages. With this in mind this study was developed and applied to selected hotels in the Miami area. Through the reviews of related literature and using a survey questionnaire, data was compiled and analyzed. This risk management safety and security program that was developed was a pragmatic analysis of how risk prevention should be implemented into the major problem areas of hotel operations. Every effort was made to be as objective and realistic in approaching these problems. This study found that while overall hotel safety and security is a multi-dimensional business practice it relies on one single fundamental concept to insure its success. That concept is the efforts by management to implement and follow through with the various risk prevention safety and security practices found in the various hotel operations. While many hotel management staffs do follow good risk prevention practices there are a good percentage who do not. 
Conclusions

This study concluded that while many of the hotels surveyed have adequate risk prevention safety and security policies in writing, implementing and following through with them is not always practiced. It appears that according to the results gathered from the questionnaire that the following conclusions are apparent.

1. Short term planning is practiced more frequently than long term planning regarding risk prevention practices within the hotel operation. For example, vulnerable areas that may involve physical changes to a guest room to make it more secure were often bypassed. Rather just changing guest room door locks was considered easier. Another example would be leaving windows without protective iron grating that faced alleyways. Instead, a flood light would be concentrated on the window and surrounding area. It appears that in many cases shortcuts were the answer to a problem.

2. Poor record keeping in all the major problem areas. Lack of documentation, for example, was frequently found with a hotel operation. For example, one hotel in the survey had taken extra security steps to make a guest room more secure. This included the use of extra locks on the doors. Unfortunately, no records were kept of this practice by the hotel. Then the key control system the hotel was currently 
using was inadequate. Poor key and lock practices negated the alleged extra security found in the hotel rooms.

3. Lastly, most hotel managers interviewed did not appear to relate to the dynamics of the major problem areas of hotel operations. These individuals were aware that problems existed, but apparently made little effort to correct them. For example, 20 percent of the hotel managers I surveyed had made no plans to contact hotel guests in the event of a hotel fire or other emergency.

4. While implementing a risk prevention safety and security program may not be a money making proposition at first, the benefits are great. Increased employee morale and pride will occur. Greater "customer satisfaction" will result as the lodging patron begins to realize he is staying in a safe and secure environment. Lastly, a long term profitability in terms of reduced insurance premiums and payouts.

Recommendations

The practice of risk prevention safety and security practices relies solely on the efforts made by management. Regardless of a hotel property's size, location or type of service, risk prevention must be a priority that has evolved from upper management. Once this risk prevention program is decided to be practiced, the following recommendations are suggested. 
1. Utilizing a risk prevention safety and security program is a perpetual hotel operations practice. Once this program comes into existence it must be followed through every day.

2. Documentation should be kept on a daily basis showing the procedures utilized to effectively utilize the risk prevention program.

3. That risk prevention safety and security must be practiced by all employees, not just management. 
APPENDIX A

You Can

You Cannot

\section{Name and Address}

1. Ask applicants to write their name and address on an application.

Ask an applicant, whose name had been changed, for their original name.

\section{Birth Place}

2 .

Inquire into the birth place of an applicant, a spouse, parent or other close relative if outside the U.S.

Ask applicants to disclose their ancestry or place of national origin.

Age

3. Ask an applicant's age,

Ask an applicant's age if it but only if the information is a bona fide is not relevant to the job. occupational qualificaGenerally do not ask to see tion, or if the data is a birth certificate. necessary to comply with state or federal minimum age laws.

\section{Religion}

4. As a general rule an applicant may be told "this is a 6-day-aweek job and employees are required to work Monday through Saturday .
Ask an applicant's religion, or ask for the name of the applicant's church, parish, pastor or the religious holidays the applicant observes. 
Appendix A (continued)

You Can

You Cannot

\section{Race or Color}

5.

Ask about an applicant's color or race or require applicants to submit a photograph with their applications.

\section{Citizenship}

6. Ask an applicant if he or she is a U.S. citizen or if he or she intends to become one.
Inquire whether an applicant, spouse or parents are naturalized or native-born citizens or ask for dates when they became citizens.

7. Ask a male or female their sex if the question is a bona fide qualification for the job. (wash room attendant, model However an official agency must indicate that gender constitutes a bona fide qualification for the job. 


\section{BIBLIOGRAPHY}

Axler, Bruce, H. Sanitation, Safety and Maintenance Management. I.T.T. Educational Services, Inc. New York. 1973 .

Bare, William $\mathrm{K}$. The Fundamentals of Fire Protection. New York: John Wiley \& Sons, 1977.

Black, Henry C. Blacks Law Dictionary. New York: West Publishing Company, 1979.

Borg, Walter. Educational Research. New York: David Mckay, Inc., 1971.

Burstein, Harvey. Management of Hotel and Motel Security. New York: Marcel Dekker, Inc., 1980.

Cournoyer, Norman G. and Marshall, Anthony G. Hotel, Restaurant and Travel Law. $2 \mathrm{~d}$ ed. Boston: Breton Publishers, 1983.

Darrow, Richard $W$. The Dartnell Public Relations Handbook. Chicago: The Dartnell Corporation, 1979.

Decter, Lewis A. Elite and Specialized Interviewing. Evanston: Northwestern University Press, 1970.

Feldman, Edwin B. Housekeeping Handbook for Institutions, Business and Industry. New York: Fell Publishers, Inc., 1978.

Fennelly, Lawrence J. Handbook of Loss Prevention and Crime Prevention. Butterworth Publishers, Inc., 1978.

Long, John D. and Gregg, Davis, W. Property and Liability Insurance Handbook. Chicago: Richard D. Irwin Publishers, Inc., 1974.

McFarland, Dalton E. Personnel Management: Theory and Practice. London: The McMillan Company, 1968.

McNeill, Joseph G. Principles of Home Inspection. Delware: The Reingold Company, 1979.

Pascel, A. Michael. Hospital Security and Safety. MD: Aspen Systems Corp., 1977. 
Robins, F. W. The Story of the Lamp. England: Kingsmead Reprints, Inc., $197 \overline{0}$.

Robinson, Robert L. How to Burglarproof Your Home. Chicago: Nelson Hall Publishers, 1977.

Roxe, Linda A. Personnel Management for the Smaller Companies. New York: American Management Associations, 1979.

Schultz, Donald $0 .$, and Service, Gregory. Security Litigation and Related Matters. New York: Charles Thomas Publishers, 1982 . 
VITA

John Charles Cochran was born in London, England on January 8, 1958. In 1966, John and his family moved to Florida. His secondary education was received while living in Miami.

After high school he entered Boston University on scholarship. In June of 1980 he received his Bachelor of Science degree in Education. The next two years were spent teaching biology and coaching football at high schools in Miami and Brunswick, Georgia.

In 1982 he left teaching to pursue his master's degree in Hospitality Management at Florida International University. He will receive his Masters of Science degree in Hospitality Management in August 198.4.

John currently is working for Hyatt Hotels in Atlanta, Georgia. 